\title{
Exercise mediated protection of diabetic heart through modulation of microRNA mediated molecular pathways
}

\author{
Jason Kar Sheng Lew ${ }^{1}$, James T. Pearson ${ }^{2,3}$, Daryl O. Schwenke ${ }^{1 *+}$ and Rajesh Katare ${ }^{1 *+}$ (D)
}

\begin{abstract}
Hyperglycaemia, hypertension, dyslipidemia and insulin resistance collectively impact on the myocardium of people with diabetes, triggering molecular, structural and myocardial abnormalities. These have been suggested to aggravate oxidative stress, systemic inflammation, myocardial lipotoxicity and impaired myocardial substrate utilization. As a consequence, this leads to the development of a spectrum of cardiovascular diseases, which may include but not limited to coronary endothelial dysfunction, and left ventricular remodelling and dysfunction. Diabetic heart disease $(\mathrm{DHD})$ is the term used to describe the presence of heart disease specifically in diabetic patients. Despite significant advances in medical research and long clinical history of anti-diabetic medications, the risk of heart failure in people with diabetes never declines. Interestingly, sustainable and long-term exercise regimen has emerged as an effective synergistic therapy to combat the cardiovascular complications in people with diabetes, although the precise molecular mechanism(s) underlying this protection remain unclear. This review provides an overview of the underlying mechanisms of hyperglycaemia- and insulin resistance-mediated DHD with a detailed discussion on the role of different intensities of exercise in mitigating these molecular alterations in diabetic heart. In particular, we provide the possible role of exercise on microRNAs, the key molecular regulators of several pathophysiological processes.
\end{abstract}

Keywords: Exercise, Diabetic heart disease, Hyperglycaemia, Insulin resistance, MicroRNA, Cardioprotection, Crosstalk effect

\section{Background}

Type-2 diabetes mellitus (T2DM) has emerged as one of the most serious health problems in modernized society, affecting 387 million people world wide [1]. Of concern, over $68 \%$ of diabetic patients will develop some form of heart disease or stroke that will ultimately prove fatal [2].

A link between DM and cardiovascular disease is undisputable. Indeed, hyperglycaemia, hypertension, dyslipidemia and insulin resistance collectively impact on the myocardium of diabetic patients, triggering several early pathophysiological molecular, structural and myocardial abnormalities [3-9], which may include but are

\footnotetext{
*Correspondence: daryl.schwenke@otago.ac.nz; rajesh.katare@otago. ac.nz

${ }^{\dagger}$ Daryl O. Schwenke and Rajesh Katare contributed equally to this work ${ }^{1}$ Department of Physiology, HeartOtago, University of Otago, 270, Great King Street, Dunedin 9010, New Zealand

Full list of author information is available at the end of the article
}

not limited to coronary endothelial and vascular dysfunction, and left ventricular remodelling and dysfunction. Due to these underlying dysfunctions, DM increases the risk for the development of a spectrum of cardiovascular disease in people with DM as compared to their non-DM counterparts. The highly cited Framingham Heart Study (FHS) showed that diabetes independently increased the risk of coronary heart disease (CHD) in men by $66 \%$ and in women by $203 \%$ when followed up for 20 years, after adjusting for the effects of age, smoking, cholesterol and blood pressure, respectively [10]. Based on the findings of FHS, it was suggested that the duration of diabetes significantly increased the risk of developing CHD and mortality [11]. More recently, a prospective study covering a 55 year span showed that, while mortality has significantly declined over time in both men and women with DM, these mortality rates still remained almost twofold higher compared to those without DM [12]. 
This review provides an overview (a) of the underlying mechanisms of hyperglycaemia- and insulin resistancemediated diabetic heart disease (DHD), juxtaposing these key factors in the pathological setting with current knowledge of exercise-induced cardioprotection, and (b) of how exercise can prevent DHD through potential miR cross-talk effects, and finally (c) on the potential roles of miRs as biomarkers to demonstrate the benefit of exercise.

\section{Diabetic heart disease}

In 1980, the term diabetic heart disease emerged as a variable combination of coronary atheroma, cardiomyopathy, microangiopathy and autonomic neuropathy [13]. It was proposed that heart disease in diabetes is not synonymous with coronary artery disease because the increased incidence of coronary risk factors in diabetes has failed to account for the observed cardiovascular mortality [13]. In agreement, the National Institute of Health $(\mathrm{NIH})$ also defined DHD as the presence of heart disease specifically in diabetic patients that encompasses coronary heart disease, heart failure and/or cardiomyopathy [14]. Of note, DHD is a broad definition encapsulating a diverse range of myocardial diseases in the diabetic population, due to the fact that (a) the aetiology is varying among individuals (e.g.: genetic susceptibility, environmental factor etc.) and (b) the mechanisms of DHD are poorly understood and defined. Hence, DHD can be a distinct clinical entity and should not be limited to a particular type of myocardial disease, rather, characterized as a myocardial disease in people with T2DM that cannot be ascribed to the individual effects of coronary artery disease, hypertension or other known cardiac disease [15].

\section{Pathogenesis of DHD}

The aetiology of DHD is multifactorial and remains unresolved. However, increasing evidence suggests that hyperglycaemia and insulin resistance are linked to the development of DHD [4, 5, 16-24]. Additional risk factors such as hypertension, obesity, hypercholesterolemia, coronary artery disease, microvascular disease and cardiac neuropathy are also known to contribute to the progression of DHD. Although a complete molecular description of DHD is beyond the scope of this review (Detailed review in [25]), a basic understanding on hyperglycaemia- and insulin resistance-mediated pathological events in the development of DHD is important in order to appreciate exercise-mediated protection of DHD as shown in Fig. 1.

\section{Hyperglycaemia-induced cardiovascular dysfunction}

Hyperglycaemia induces activation of polyol pathway (through the activation of aldose reductase), protein

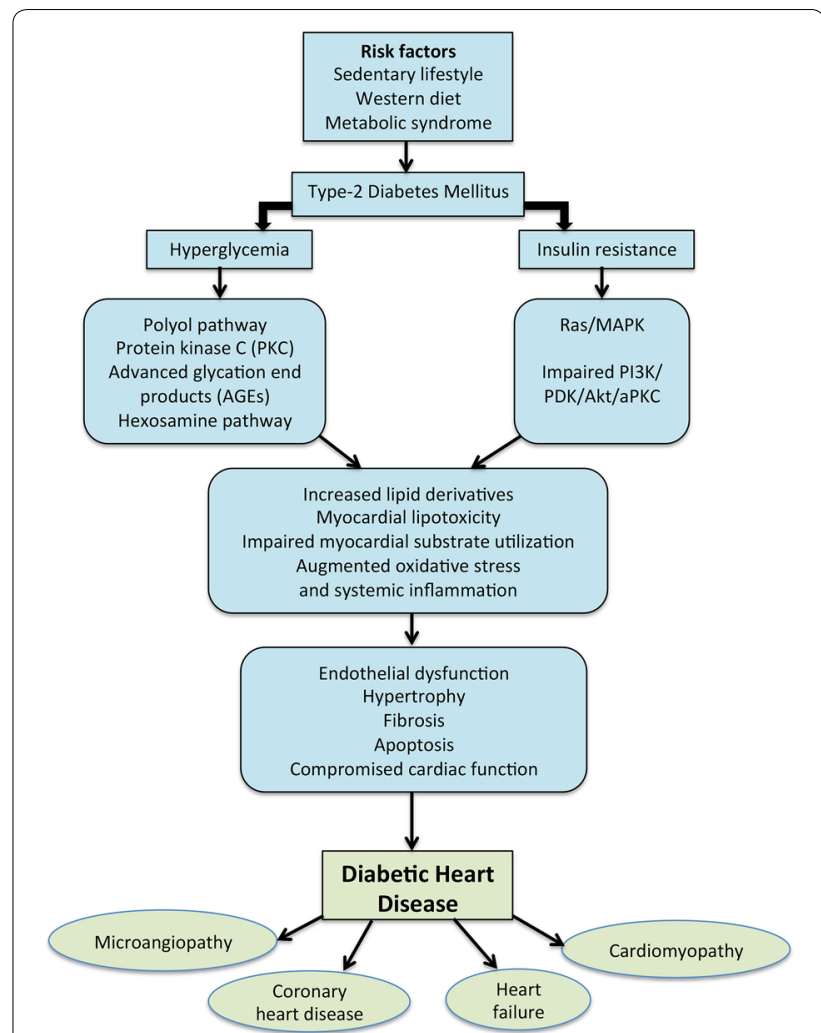

Fig. 1 Pathogenesis of diabetic heart disease

kinase-C pathway (PKC), advanced glycation end products (AGEs) pathway and hexosamine pathway, all of which have the potential to increase myocardial oxidative stress $[26,27]$ and cardiovascular dysfunction in diabetes.

Increased intracellular glucose concentration increases aldose reductase activity, which uses excess nicotinamide adenine dinucleotide phosphate (NADPH) as a cofactor to convert glucose to sorbitol, resulting in the depletion of intracellular NADPH [28]. This eventually reduces the generation of reduced glutathione (GSH), an intracellular antioxidant $[29,30]$. As a result, the net production of GSH decreases, hindering the antioxidant capacity to counteract the augmented intracellular oxidative stress caused by high glucose. Altered aldose reductase activity has been reported to predispose the myocardium to ischemic insult [31]. Indeed, inhibition of aldose reductase was able to protect isolated type-1 diabetic rat hearts from ischemia reperfusion injury by preserving highenergy phosphates and maintaining a lower cytosolic $\mathrm{NADH} / \mathrm{NAD}+$ ratio [31]. In a clinical study, one-year of aldose reductase inhibition treatment was able to stabilize and partially reverse left ventricular abnormalities in diabetics with neuropathy [32].

The hyperglycaemia-mediated increase in total diacylglycerol (DAG) from the glycolytic intermediate, 
glycerol-3-phosphate (G3P), can trigger the activation of DAG-protein kinase C (DAG-PKC) [33]. Intracellular hyperglycaemia activates PKC- $\beta$ and $-\delta$ isoforms, which induce activation of pro-inflammatory genes [e.g. p38 and nuclear factor kappa-light-chain-enhancer of activated $\mathrm{B}$ cell (NK-KB)] and microvascular matrix remodelling, impair vascular permeability and inhibit endothelial nitric oxide synthase (eNOS) [34-38]. In addition, this pathway also activates NADPH oxidase, causing an intracellular overproduction of reactive oxygen species (ROS) $[39,40]$. In support to this notion, transgenic mice with cardiac-specific overexpression of PKC- $\beta_{2}$ exhibited cardiac hypertrophy, fibrosis, dystrophic calcification and increased cardiomyocytes death [41].

The increased concentration of glycolytic intermediates such as G3P, glucose-6-phosphate and fructose accelerate the production of advanced glycation end products (AGEs) through a non-enzymatic reaction between proteins, lipids or nucleic acids (reviewed in [42]). Increased AGEs have been demonstrated to contribute to the pathogenesis of DHD by altering the functional and elastic properties of the blood vessels, vascular tone and extracellular matrix [43-46]. In fact, binding of AGE to its receptor (RAGE) on endothelial cells, smooth muscle cells, and macrophages triggers a series of molecular pathways, contributing to the activation of inflammatory signalling cascades, oxidative stress, increased vascular permeability, atherogenesis and vasoconstriction, leading to diverse vascular dysfunction [47-51]. To support this notion, in a series of elegant studies conducted by Zitman-Gal et al., the treatment of AGE (diabetic-like environment) on endothelial cells (ECs) and vascular smooth muscle cells was able to induce significant expression of various inflammatory markers such as Kruppel-like factor, IL-6, IL-8 and thioredoxin-interacting protein (TXNIP), suggesting a direct role for the adverse effect of AGE in the development of diabetic vascular complications [52-54]. In addition, the level of circulating AGE has been suggested as an independent predictor of the prognosis for heart failure patients [55]. Elevated AGE level has also been suggested to be highly correlated with insulin resistance in T2DM [56].

Glucose metabolism through hexosamine pathway is relatively low (1-3\%) in physiological conditions. In this pathway, fructose-6-phosphate is first converted to glucosamine-6-phosphate (GlcN-6-P) by glutamine:fructose- 6 -phosphate amidotransferase (GFAT). Subsequently, GlcN-6-P is metabolized to form uridine diphosphate (UDP)- $N$-acetylglucosamine. Enzyme O-linked $N$-acetylglucosamine transferase (O-GlcNAc) utilizes UDP- $N$-acetylglucosamine to modify serine and threonine on cytosolic and nuclear proteins (reviewed in [57]). Importantly, elevated glucose concentration is known to induce O-GlcNAc expression $[26,58]$. Altered O-GlcNAcylation has been shown to associate with impaired $\mathrm{Ca}^{2+}$ handling protein [59], fibrosis [22], insulin signalling [60,61], cardiomyocyte hypertrophy [62], impaired relaxation and vascular function [63].

\section{Insulin resistance-mediated cardiovascular dysfunction}

Diabetes impairs the PI3K-mediated pro-survival signalling cascade, while preserving the mitogenic Ras/ MAPK-dependent pathway [74-76], thereby shifting the balance in favour of atherogenic and mitogenic actions of insulin. Insulin receptor substrate-1 (IRS) is required for the activation of phosphoinositide-3 kinase/phosphoinositide-dependent kinase 1/protein kinase B/atypical protein kinase C (PI3K/PDK1/Akt/aPKC) cascade, which regulates translocation of glucose transporter (GLUT)-1 and -4 proteins $[64,65]$, nitric oxide production [66], apoptosis [67], autophagy [68] and fat metabolism [69]. In contrast, activation of Ras-mitogen-activated protein kinase-dependent pathway (Ras/MAPK) (reviewed in [70]) promotes cellular differentiation, proliferation, apoptosis through its downstream effectors: c-Jun N-terminal kinase (JNK), extracellular signal-regulated kinase (ERK) and p38 MAPK (reviewed in [71-73]).

\section{Effects of insulin resistance on myocardial lipotoxicity}

Excessive FFA and lipid oxidation are often seen in diabetic heart, causing them to lose the flexibility to switch its source of energy between FFA and glucose [77, 78]. This reduction in insulin-mediated glucose uptake forces cardiomyocytes to heavily rely on FFA oxidation for their energy source. Since myocardial tissue utilizes more oxygen to metabolize a single molecule of FFA compared to glucose molecule, the oxygen cost to produce adenosine triphosphate (ATP) in FFA oxidation is higher than glucose metabolism [21, 79]. Of importance, increased oxygen cost reduces the cardiac efficiency that is associated with the development of dilated cardiomyopathy, heart failure and ventricular dysfunction [20,79-81].

\section{Effects of insulin resistance on oxidative stress}

Insulin resistance is also associated with the overproduction of oxidants due to the proportional increase of electron donors to the mitochondrial electron transport chain during FFA oxidation, which inactivates two important antioxidants: prostacyclin synthase and eNOS [82]. In line with this, inhibition of FFA release from adipocytes and inhibition of the rate-limiting enzyme for FFA oxidation completely reversed ROS production in insulin resistant but not in non-diabetic rodent models [82]. Consequently, overproduction of superoxide inhibits IRS-1-induced PI3K-dependent pathway activation 
[83], thereby suppressing the pro-survival pathways (reviewed in $[84,85]$ ).

\section{Effects of insulin resistance on systemic inflammation}

Adipokines are cytokines that are constantly produced by adipocytes, such as tumour necrosis factor- alpha (TNF- $\alpha$ ), interleukin-6 (IL-6) and angiotensinogen, In addition to adipocyte sources, FFA-induced and electron uncoupling-evoked ROS can also directly stimulate proinflammatory cytokine production through the activation of nuclear factor kappa B (NFkB) [86]. Eventually, overproduction of these cytokines is considered to inhibit insulin-mediated metabolic effects through several mechanisms. Firstly, TNF- $\alpha$ can attenuate PI3K/ Akt-dependent cell survival signalling through phosphorylation of IRS-1 at Serine ${ }^{307}$ [87] and activation of p38 MAPK and I-kappaB kinase $\beta$ (IKK $\beta$ ) [88]. Secondly, both TNF- $\alpha$ and IL- 6 can stimulate suppressor of cytokinesignalling- 1 and -3 proteins (SOCS-1, -3 ) expression [89, 90]. SOCS protein then inhibit the coupling of IRS-1 and PI3K proteins either by ubiquitination of IRS proteins for proteasomal degradation [91] or through the inhibition of tyrosine phosphorylation of IRS protein [92]. Taken together, inhibition of upstream mediators of PI3K protein induced by augmented cytokines and ROS can result in the suppression of insulin-mediated metabolic regulation.

\section{Pharmacological Intervention for DHD}

The current clinical treatment for diabetes-associated myocardial dysfunction is solely dependent on a 'cocktail' of drugs and 'symptomatic treatment' approaches [93-95]. For instance, patients with diabetes are often prescribed a plethora of drugs, which include multiple glucose lowering agents, antihypertensive drugs, anticholesterol and/or aspirin for cardiac health [93-95]. The use of glucose lowering agents may decrease the risk of microvascular complications such as nephropathy, retinopathy and neuropathy [96, 97]. However, despite their long clinical treatment for diabetes, their efficacies in the improvement of DHD still remain speculative. In essence, there is still no single drug that specifically and effectively treats DHD, primarily due to the fact that the mechanism(s) underpinning DHD are poorly understood and are multi-factorial. Table 1 summarizes the common medications used in combination to alleviate the symptoms of DHD. These medications primarily target DHD symptoms and sometimes act as secondarily to reduce the risk of diabetes complications.

According to the United Kingdom Prospective Diabetes Study (UKPDS), intensive blood glucose control (with fasting blood glucose $<6 \mathrm{mmol} / \mathrm{L}$ ) in people with T2DM over a period of 10 -years significantly reduced microvascular complications, as well as the deaths associated with diabetes-related complications such as hyperglycaemia, angina and heart failure [96]. In contrast, large-scale clinical studies such as Action in Diabetes and Vascular Disease (ADVANCE) [97], Action to Control Cardiovascular Risk in Diabetes (ACCORD) [98] and Veterans Affairs Diabetes Trial (VADT) [99] have failed to replicate the cardioprotective results as reported in UKPDS [96], even with a well-controlled $\mathrm{HbA}_{1 \mathrm{c}}$ of $<7 \%$ in T2DM. It is noteworthy, that the ACCORD study was prematurely terminated due to the unacceptably high mortality rate observed in T2DM individuals subjected to intensive glycaemic control [98]. Consistent with this finding, a recent meta-analysis revealed that intensive diabetic care enhance the risk of developing heart failure by $14 \%$ in diabetic patients when compared to those who received standard care [100]. Ultimately, an effective therapeutic regime for preventing the onset of DHD is clinically imperative, yet remains to be identified.

\section{Physical exercise as an intervention}

Increased physical activity or active lifestyle has emerged as an effective therapeutic regimen to synergize the effects of pharmacotherapy in diabetic management and significantly reduce the risks of cardiovascular events [101-109], although the precise molecular mechanism(s) of action remain unclear. The American Diabetes Association (ADA) and the Diabetes Prevention Program (DPP) have advocated physical exercise as a non-pharmacological adjuvant to bolster the conventional management and prevention of DHD [110, 111]. A series of clinical and experimental studies has demonstrated that an appropriate volume and intensity of exercise can ameliorate myocardial dysfunction through the improvement of maximum oxygen consumption $\left(\mathrm{VO}_{2 \max }\right)$, left ventricular ejection fraction (LVEF), LV diastolic and systolic volumes, ventilatory threshold, cardiac output and diastolic function (E/A ratio) [106, 108, 112-119].

\section{Exercise-mediated cardioprotection}

Exercise has been suggested to restore myocardial function through the improvement of $\mathrm{VO}_{2 \max }$, endothelial function, left ventricular systolic and diastolic function and blood pressure (Fig. 2) [106, 108, 109, 115, 120]. $\mathrm{VO}_{2 \max }$, a strong indicator for cardiorespiratory fitness and an independent predictor of cardiovascular mortality [121], was improved by $12-16 \%$ in obese postmenopausal women and obese individuals with T2DM in response to moderate-intensity exercise [122, 123]. Tjonna et al. [108] demonstrated that both moderate- and high-intensity exercise regimes were able to improve $\mathrm{VO}_{2 \max }$ of metabolic syndrome patients. Data on cardioprotective effects of low-intensity exercise is sparse. This could be due to 


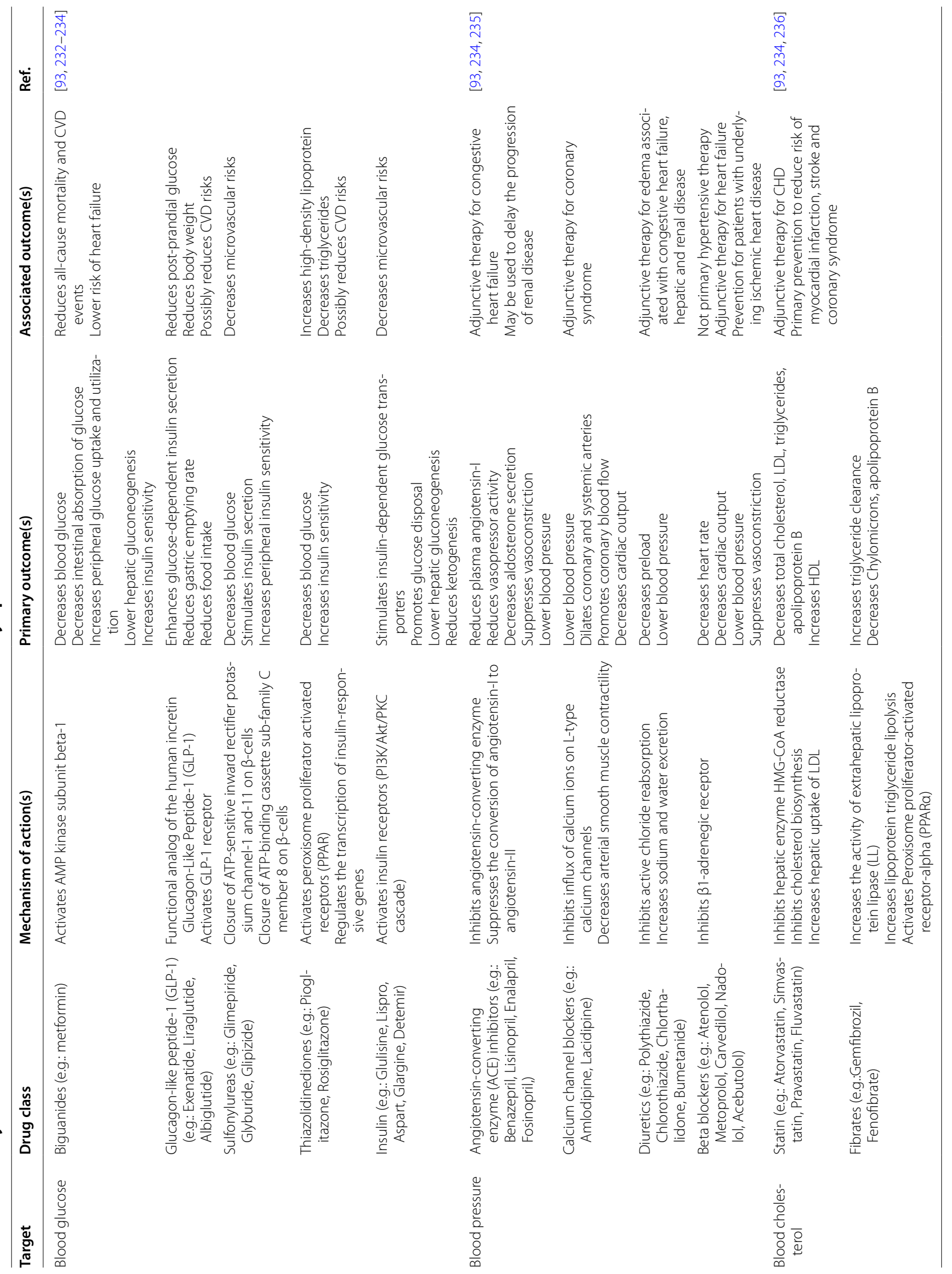




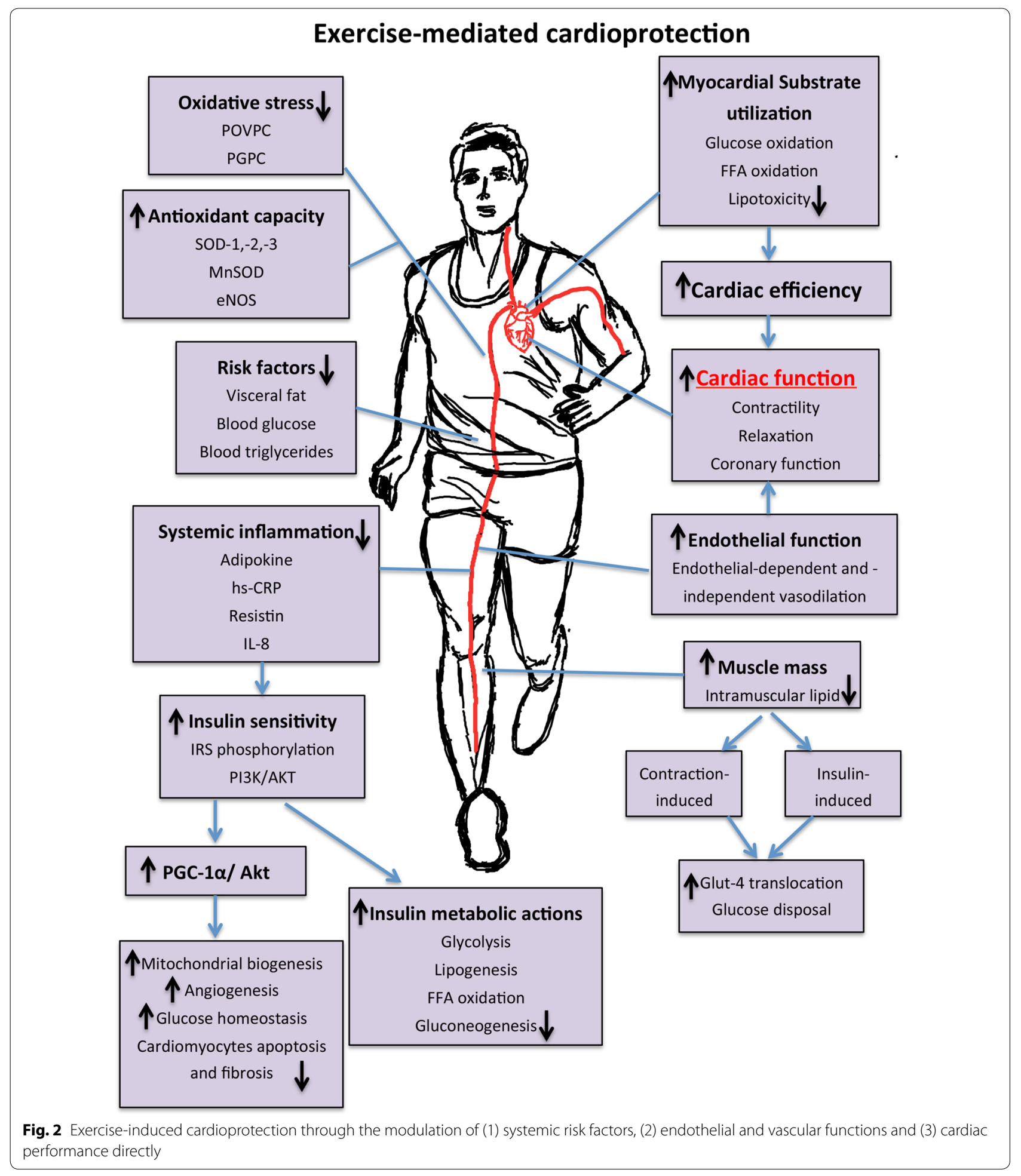

the fact that low-intensity exercise may not meet the recommended minimum threshold of exercise intensity (e.g. $>50 \%$ of $\mathrm{VO}_{2 \max }$ ) for improving cardiorespiratory endurance [124].
Cardiac tissue has an extremely high metabolic demand and, consequently, cardiac function is highly dependent on adequate coronary blood flow. Thus, coronary artery dysfunction directly impacts on optimal 
myocardial function. An eight-week moderate-intensity exercise regime in individuals with T2DM significantly improved endothelial function in the brachial artery as indicated by the improved flow-mediated dilation [125]. In another study, a 14-month moderate-intensity resistant training in adults with T2DM was able to improve the endothelial-dependent and -independent vasodilation in response to acetylcholine and sodium nitroprusside, respectively [126]. Of note, assessment of endothelial function in these studies was purely based on the brachial artery but not directly on the coronary endothelium, even though peripheral endothelial function has been suggested to correlate with function of the coronary endothelium [127, 128]. However, direct evidence of the beneficial effect of exercise on coronary artery function has been demonstrated in diabetic rodent models [113, $129,130]$.

\section{Exercise mediated improvement}

\section{of hyperglycaemia-induced cardiovascular dysfunction}

As mentioned above, strict control of blood glucose with pharmacological intervention alone is not sufficient to reduce the risk of major cardiovascular events in people with T2DM. Indeed, intensive diabetic pharmacotherapy can even exacerbate cardiovascular events in diabetes patients [98, 100, 131]. Yet, exercise as an adjunct with anti-diabetic treatment (either with insulin or oral hypoglycaemic drugs) reduced the incidence of cardiovascular events [101-103], and improved $\mathrm{VO}_{2 \max }$ in T2DM patients [132]. Meta-analyses on the association between physical exercise with the risk of all-cause mortality and cardiovascular disease further demonstrated that increased physical activity was inversely correlated with cardiovascular risk and mortality in T2DM [133, 134]. Together, this evidence strongly advocates that active physical activity synergizes the effects of anti-hyperglycaemic drugs in the management of diabetic complications, in particular, cardiovascular dysfunction. The exact mechanism(s) that underpin this intriguing synergistic effect remain unclear.

Interestingly, the reported improvements of glycaemic control and myocardial function appear to be linked to a reduction in adiposity and an improvement in insulin sensitivity [122, 135-138]. Two recent randomized controlled trials reported that obese T2DM participants in weight loss programs showed improved glycaemic status and lowered triglycerides level, which was associated with a decreased risk of cardiovascular disease [139, 140]. Indeed, decreased visceral fat is associated with lower levels of adipokines that are crucial determinants in metabolic and vascular homeostasis (reviewed in [73]). Adipokines are known to negatively modulate SOCS3mediated phosphorylation of IRS-1 protein. Therefore, exercise-mediated reduction in adipokines may restore activation of IRS-1 mediated PI3K-dependent signalling.

Moreover, improved insulin sensitivity can effectively elicit glucose disposal and reduce the amount of insulin required to maintain normal glucose levels [122, 135, 136]. Improved muscular strength $[114,141]$ and muscle density [122] following exercise can also facilitate glucose uptake independent of insulin action due to increased muscular contractions, which enhance translocation of GLUT-4 proteins to the skeletal muscle and sarcolemma (Fig. 2) [142]. Oguri and colleagues [143] demonstrated a significant increase of systemic glucose uptake in T2DM individuals and enhanced GLUT-4 membrane translocation in individuals after a single bout of moderate-intensity exercise Collectively, the evidence in the literature advocates that diabetic pharmacotherapy alone does not reduce the risks of cardiovascular events; rather the addition of routine physical exercise can synergise with the treatment through the improvement of insulin sensitivity and enhancement of glucose utilization.

\section{Exercise mediated improvement of insulin resistance-induced lipotoxicity}

Using proton magnetic resonance spectroscopy $\left({ }^{1} \mathrm{H}-\right.$ MRS), Sai et al. [144] demonstrated a marked reduction in myocardial triglyceride content and a significant improvement in cardiac function in endurance athletes who were exercising for 5 days a week. In contrast, Schrauwen-Hinderling et al. [145] showed that combined endurance and strength training 3 times per week for 12 weeks improved insulin sensitivity, $\mathrm{VO}_{2 \max }$, LVEF and cardiac output in obese T2DM individuals without altering the cardiac lipid content. Although the design of the exercise training protocol would certainly impact on cardiac lipid content, it is also possible that improvement of cardiac function is independent of cardiac lipid content. Several other studies have also confirmed that a cardioprotective effect of exercise in diabetes is primarily through the improvement of myocardial substrate utilization by correcting the mismatch between myocardial FFA uptake and oxidative metabolism (Fig. 2) [112, 117, 146].

Hafstad et al. [112] reported an increase in myocardial glucose oxidation and a concomitant reduction in FFA oxidation in the hearts of $d b / d b$ mice following a high-intensity treadmill exercise. This effect was accompanied by improved cardiac efficiency and cardiac mitochondrial respiratory capacity. Similarly, Broderick et al. [117] reported higher myocardial glucose oxidation and enhanced cardiac function after myocardial ischemia in diabetic rats subjected to high-intensity exercise. This might be attributable to an increase in sarcolemmal GLUT-4 proteins [147]. The increase in myocardial 
glucose uptake protects the heart by shifting away from over reliance on FFA oxidation.

Although it remains uncertain as to whether this experimental data can be translated into the clinical setting, due to limited clinical studies, there have been some studies that have provided important insight concerning the effect of exercise on cardiac function and glucose utilization in diabetic patients. For instance, endurance exercise in elderly men with impaired glucose tolerance improved total GLUT-4 protein expression, reduced intramuscular lipid content and increased FFA oxidation capacity in the vastus lateralis muscle [148]. With respect to myocardial substrate utilization, moderate-intensity exercise substantially increased myocardial lactate and glucose uptake and oxidation in young healthy subjects [149]. Sato et al. [150] suggested that exercise could reduce myocardial uptake rate of FFA and glutamate and enhance myocardial uptake of glucose, lactate and glutamate in ischemic heart disease patients.

\section{Exercise-mediated improvement of oxidative stress}

There is an unambiguous relationship between oxidative stress and cardiac function (reviewed in [151, 152]). A considerable number of clinical studies have demonstrated the favourable effect of exercise on the systemic level of oxidative stress in diabetic individuals (Fig. 2) [153-159]. A recent randomized controlled trial on T2DM individuals who were subjected to 12-month of supervised aerobic, resistance and flexibility training demonstrated a reduction in plasma oxidative stress markers, 1-palmitoyl-2-(5-oxovaleroyl)-sn-glycero-3-phosphorylcholine (POVPC) and 1-palmitoyl-2-glutaroyl-sn-glycero-3-phosphorylcholine (PGPC) compared to those who received only standard medical care. Exercise also improved lowdensity lipoprotein (LDL) cholesterol, $\mathrm{VO}_{2 \max }$, insulin sensitivity and waist circumference [155]. Concomitantly, T2DM individuals who received 3 months of yoga therapy achieved a $20 \%$ reduction in malondialdehyde (MDA), a lipid peroxidation oxidative marker, compared to the non-exercise group. A decrease in oxidative stress was accompanied by enhanced glutathione and vitamin $\mathrm{C}$ and reduction in glycated haemoglobin $\left(\mathrm{HbA}_{1 \mathrm{c}}\right)$ and fasting plasma glucose [156]. Again, this data strongly supports the notion that exercise has a synergistic effect as an adjuvant to further bolster the conventional therapeutic intervention in the management of diabetes.

Animal models of exercise have also consistently revealed significant improvements in cardiac antioxidant capacity and reduced oxidative stress (Fig. 2). Lee et al. [113] demonstrated an increase in the levels of antioxidants superoxide dismutase- 1 and -2 (SOD-1 and SOD2 ) and eNOS in the diabetic heart following a 10-week moderate-intensity aerobic exercise. This was associated with the improvement of coronary endothelial function in diabetic mice. Moreover, Moien-Afshari et al. [130] demonstrated a significant increase in mitochondrial SOD (MnSOD) and extracellular SOD (SOD-3) in the diabetic mice heart after an 8-week exercise regime.

The underlying mechanisms of how induction of antioxidants and restoration of redox status may benefit DHD are diverse. Some reports suggest that exercise is able to upregulate heat shock protein expressions to increase the antioxidant capacity in diabetes [160]. Exercise has also been shown to activate the antioxidant mediator, nuclear erythroid 2 p45-related factor 2 (Nrf2), a redoxsensitive transcription factor, to increase the expression of myocardial glutathione to buffer diabetes-induced oxidative stress. Depletion of Nrf2 abolished the expression of myocardial antioxidant genes such as catalase, glucose-6-phosphate dehydrogenase (G6pd), $\gamma$-glutamyl cysteine ligase-modulatory (Gclm), $\gamma$-glutamyl cysteine ligase-catalytic $(G c l c)$, glutathione reductase $(G s r)$, and $\mathrm{NAD}(\mathrm{P}) \mathrm{H}$-quinone oxydase-1(Nqo1) [161], thereby compromising the redox status in the myocardium. Furthermore, several studies have demonstrated an increase of ischemia-modified albumin (IMA) in T2DM individuals. IMA has been reported as an indicator of ischemic index, oxidative stress and peripheral arterial disease [162-164].

The long-term and regular incorporation of moderateintensity exercise (e.g. walking) in T2DM individuals was able to prevent the increase in IMA and oxidative stress and hence reduce the risk of ischemia through induction antioxidants [154]. Once again, collectively, these data strongly suggested that a consistent and regular moderate-exercise regime is capable of buffering the hyperglycaemic- and insulin resistant-mediated oxidative stress in both the myocardium and systemic circulation, which could eventually prevent the development of diabetic cardiac dysfunction.

\section{Exercise-mediated protection against pro-inflammatory cytokines}

It has been reported that exercise can reduce systemic inflammation in T2DM. An 18-year follow up study in middle-aged T2DM individuals who were highly involved in at least moderate-intensity physical exercise or greater reported a marked reduction in high-sensitivity C-reactive protein (hs-CRP), which was significantly associated with a reduction in total cardiovascular and coronary heart disease mortality [165]. Interestingly, exercise induced reduction in hs-CRP has been demonstrated to be related to an improved homeostatic model assessment-insulin resistance (HOMA-IR) index [123], an independent predictor of cardiovascular disease in T2DM [18] and also a measure of insulin resistance and $\beta$-cell function [166]. Obese T2DM individuals who 
underwent 16-week aerobic exercise training achieved a substantial reduction in resistin [123], a pro-inflammatory adipokine that is suggested to be associated with atherosclerosis and heart failure $[167,168]$. This change was coupled with reductions in hs-CRP and IL-18 and improved $\mathrm{VO}_{2 \max }$.

As discussed above, proinflammatory cytokines suppress IRS-mediate insulin metabolic actions, which in turn are attributed to the cardiometabolic dysfunction. Therefore, improvement of the persistent low-grade systemic inflammation in the diabetic condition with exercise is believed to result from an improvement in insulin sensitivity by restoring the IRS-induced phosphorylation of PI3K-dependent pathway, thereby ameliorating the cardiovascular events.

\section{Exercise-mediated improvement of pro-survival signalling cascade}

Restoration of altered pro-survival signalling cascade could play a major role in exercise-induced cardioprotection. As discussed above, impairment in insulin-mediated PI3K-dependent pathway alters the cell-signalling cascade. Therefore, restoration of this pathway can significantly improve insulin sensitivity and elicit insulinassociated metabolic effects by modulating glucose disposal, gluconeogenesis, lipogenesis and FFA oxidation (reviewed in [70, 73]). In animal models, endurance exercise has been shown to substantially improve insulin responsiveness through the phosphorylation of IRS-associated PI3K pathway, particularly IRS-1 and -2 proteins, Akt and its downstream substrate AS160 [169-173]. Other signalling pathways such as liverkinase B1 (LKB1)-mediated phosphorylation of adenosine monophosphate-activated protein kinase (AMPK) pathway in skeletal muscle [174], adaptor protein phosphotyrosine interaction $\mathrm{PH}$ domain and leucine zipper containing 1 (APPL1)-mediated Akt pathway in liver [175] have also been reported to potentiate the metabolic actions of insulin.

Recently, Kjøbsted et al. [176] highlighted the physiological role of AMPK-Tre-2/BUB2/CDC16 domain family member 4 (TBC1D4) signalling axis in mediating the improvement of muscle insulin sensitivity after exercise. AMPK has also been suggested to play critical roles in regulating microvascular blood flow, glucose uptake and hence is considered to be a potential therapeutic insulin sensitizer [177].

Emerging evidence indicates the importance of peroxisome proliferator-activated receptor gamma coactivator 1-alpha (PGC-1 $\alpha)$, a transcriptional coactivator, in exercise-mediated cardioprotection. PGC- $1 \alpha$ is predominantly expressed in tissues with high oxidative capacity such as the heart, skeletal muscle, liver and brown adipose tissue, which has profound effects on mitochondrial biogenesis and energy metabolism [178-180]. Attenuated PGC-1 $\alpha$ level leads to metabolic disorders. Adipose-specific PGC- $1 \alpha$ deficiency in mice manifested the characteristics of T2DM, such as insulin resistance, impaired glucose tolerance and lipid metabolism, resulting in suppressed mitochondrial and thermogenic gene expressions in adipocytes [181]. Interestingly, the combined effects of enhanced PGC- $1 \alpha$ expression and exercise training in mice improved glucose and insulin tolerance, suggesting a promising role for exerciseinduced PGC- $1 \alpha$ in treating metabolic disorders [182].

In addition to its effect on metabolism, Chinsomboon et al. [183] demonstrated the beneficial effects of exercise induced PGC- $1 \alpha$ on angiogenesis. Using a genetic knockdown mouse model, they demonstrated that $\beta$-adrenergic stimulation during exercise is essential to induce activation of the PGC-1 $\alpha /$ estrogen related receptor- $\alpha(E R R \alpha)$ axis, which in turn upregulates vascular endothelial growth factor (VEGF) and plateletderived growth factor (PDGF) expressions to markedly increase the capillary density in skeletal muscle [183]. Moreover, 15 weeks of moderate intensity treadmill exercise was also shown to attenuate diabetes-induced cardiac dysfunction and remodelling via PGC- $1 \alpha$ and Akt activation in $d b / d b$ mice, which possibly reduced myocardial apoptosis and fibrosis [173]. Taken together, induction of PGC- $1 \alpha$ activation by exercise has various positive outcomes such as increasing insulin sensitivity, glucose transporters, as well as improving glucose homeostasis and fatty acid oxidation, [182, 184-187], all of which are important for the amelioration of the progression of DHD (Fig. 2).

Several clinical studies also support the notion that exercise training is able to enhance IRS-mediated PI3Ksignalling in diabetic patients $[188,189]$. Kirwan et al. [188] reported an enhancement of insulin-induced IRS1 -associated PI3K activation in vastus lateralis muscle of healthy aerobic exercise trained individuals compared to sedentary or untrained participants. The $\mathrm{VO}_{2 \max }$ was also $26 \%$ higher in trained individuals, reflecting a positive correlation between $\mathrm{VO}_{2 \max }$ and PI3K activation

Jorge et al. [190] compared the effects of aerobic, resistance and combined exercise on insulin signalling in T2DM individuals, and demonstrated 65 and 90\% induction of IRS-1 expression in the skeletal muscles of resistance group and combined exercise group, respectively. Of importance, plasma glucose, blood pressure, systemic inflammatory cytokine and lipid profiles have improved in all groups of exercise [190]. Based on this evidence, restoration of IRS-mediated PI3K-dependent pathway could be one of the determining factors in mediating exercise-induced protection of the diabetic heart. 


\section{Exercise-mediated differential expression of cardiovascular microRNAs}

As stated above, metabolic dysregulation adversely triggers uncoupling of key cellular pathways from the very early stage of diabetes, which ultimately manifest as the functional and structural cardiac changes with the evolution of diabetes. These pathological changes appear to be closely associated with changes in the expression of microRNA (miR).

MiRs are small non-coding RNA molecules which are $\sim 22$ nucleotides long and regulate transcriptional and post-transcriptional gene expression (reviewed in [191]). A single miR can modulate complex pathological processes through their pleiotropic effects on multiple targets in disease development. The modulation of miRs in exercise-induced cardioprotection has received very little attention, yet it is an intriguing line of research that warrants urgent investigation. In the following section, we provide evidence to demonstrate that dynamic changes in miRs in response to exercise are able to induce significant cardioprotection. Table 2 summarizes the role of miRs in the development of cardiovascular disease and the following section will describe the role of each miR in detail.

\section{Exercise and muscle-specific miRs (miR-1, -133 and -499)}

Several studies have proposed a potential role of miR-133 in the pathogenesis of heart disease [192-195], although its specific role in DHD still remains to be elucidated. Interestingly, the functional targets of miR-133, which include but are not limited to connective tissue growth factor (CTGF) [192, 195], B-cell lymphoma-2 like 11 (Bim), B-cell lymphoma-2 modifying factor (Bmf) [196] and Caspase-9 [197], have been extensively implicated in cardiac pathological remodelling and cell death. Hence, down-regulation of miR-133 has been associated with cardiac apoptosis, hypertrophy and myocardial matrix remodelling [192, 193, 197], all of which are known to induce adverse cardiac dysfunction in cardiovascular disease, possibly in DHD as well.

In a streptozotocin-induced diabetic cardiomyopathy mouse model, Chen et al. [195] reported an apparent link between a reduced myocardial expression of miR-133 and an augmented expression of fibrosis markers. Moreover, transgenic overexpression of miR-133 reversed diabetes-induced cardiac remodelling by attenuating these fibrotic markers. Concomitantly, in vitro induction of hypertrophy in cardiomyocytes by high glucose resulted in altered expression of miR-133 with enhanced expression of atrial natriuretic peptide $(A n p)$ and brain natriuretic peptide $(B n p)$ mRNAs, indicators of pathological cardiac hypertrophy. The overexpression of miR-133 in neonatal rat cardiomyocytes attenuated the hypertrophic change via inhibition of serum and glucocorticoid-regulated kinase 1 (SGK1) and insulin-like growth factor 1 receptor (IGF1R) proteins [193].

Although it is not clear whether exercise can normalize miR-133 expression in the myocardium, it is exciting to consider that exercise might be able to restore the expression of miR-133 by acting through a cross-talk effect. For example, both acute endurance and resistance exercise training in healthy male volunteers were able to enhance miR-133 expression in the vastus lateralis muscles [198, 199]. In addition, an increased level of miR-133 following marathon training appeared to be associated with improved $\mathrm{VO}_{2 \max }[200]$. Moreover, endurance exercise elevated circulating levels of miR-133 in healthy individuals after either an acute bout of aerobic exercise, or endurance training [201, 202]. Similarly, subjecting T2DM mice to a 10-week swimming exercise regime increased the expression of miR-133 in cardiac tissue with improved contractile function and decreased

Table 2 Summary of the known roles of miRs in the development of cardiovascular diseases [221]

\begin{tabular}{|c|c|c|c|c|}
\hline MicroRNA & $\begin{array}{l}\text { Expression in cardiovascular } \\
\text { disease }\end{array}$ & Direct target(s) & Pathophysiological effect(s) & Reference(s) \\
\hline MiR-1 & Downregulated & $\mathrm{JCN}$, Fbln2 & $\begin{array}{l}\text { Cardiac hypertrophy, remodelling, } \\
\text { arrhythmias, cardiomyocyte apop- } \\
\text { tosis }\end{array}$ & {$[197,207-209,237]$} \\
\hline MiR-133 & Downregulated & CTGF, Bim, Bmf, Caspase-9 & $\begin{array}{l}\text { Cardiac remodelling, cardiomyocyte } \\
\text { apoptosis }\end{array}$ & {$[192,195-197]$} \\
\hline MiR-499 & Downregulated & Pdcd4, Pacs2, Dyrk2 & Cardiomyocyte apoptosis & [210] \\
\hline MiR-222 & Downregulated & Hmbox-1, HIPK-1, HIPK-2, p27, p57 & $\begin{array}{l}\text { Cardiomyocyte apoptosis, cellular } \\
\text { senescence, coronary artery disease, } \\
\text { atherosclerosis }\end{array}$ & {$[211-214]$} \\
\hline MiR-126 & Downregulated & SPRED1, PIK3R2 & $\begin{array}{l}\text { Coronary artery disease, atherosclero- } \\
\text { sis, endothelial cell apoptosis }\end{array}$ & {$[215-217]$} \\
\hline
\end{tabular}

Junctin, JCN; Fibulin-2, Fbln2; Connective tissue growth factor, CTGF; B-cell lymphoma-2 like 11, Bim; B-cell lymphoma-2 modifying factor, Bmf; Programmed cell death 4, Pdcd4; Phosphofurin acidic cluster sorting protein 2, Pacs2; Dual specificity tyrosine phosphorylation regulated kinase 2, Dyrk2; Homeodomain interacting protein kinase, HIPK; Homeobox containing 1, Hmbox1; Sprout related EVH1 domain containing 1, SPRED; Phosphoinositide-3-kinase regulatory subunit 2, PIK3R2 
matrix metallopeptidase-9 (MMP-9), an extracellular matrix regulator protein [203]. Since miR-133 is reported to be expressed and enriched in both cardiac and skeletal muscles (review in [191]), it is possible that miR-133 is secreted into the circulation from skeletal muscle after a bout of exercise, which then travels to the cardiomyocytes to suppress fibrotic markers and reduce cardiac hypertrophy (Fig. 3).

Frequently, skeletal muscle is referred as an endocrine organ due to its ability to release factors (myokines) that communicate with other distant organs or tissues through a 'cross-talk' effect to maintain homeostasis. For example, exercise has been shown to trigger the release of IL-6 from skeletal muscle and ultimately contribute to glucose metabolism [204, 205]. miRs can be released in a similar manner following exercise. Importantly our recent studies showed marked downregulation of muscle-specific miRs also known as myomiRs such as miR-1, -133 and -499 in the human diabetic heart [206]. Therefore, it is possible that exercise could activate the myomiRs in skeletal muscle which are released into the

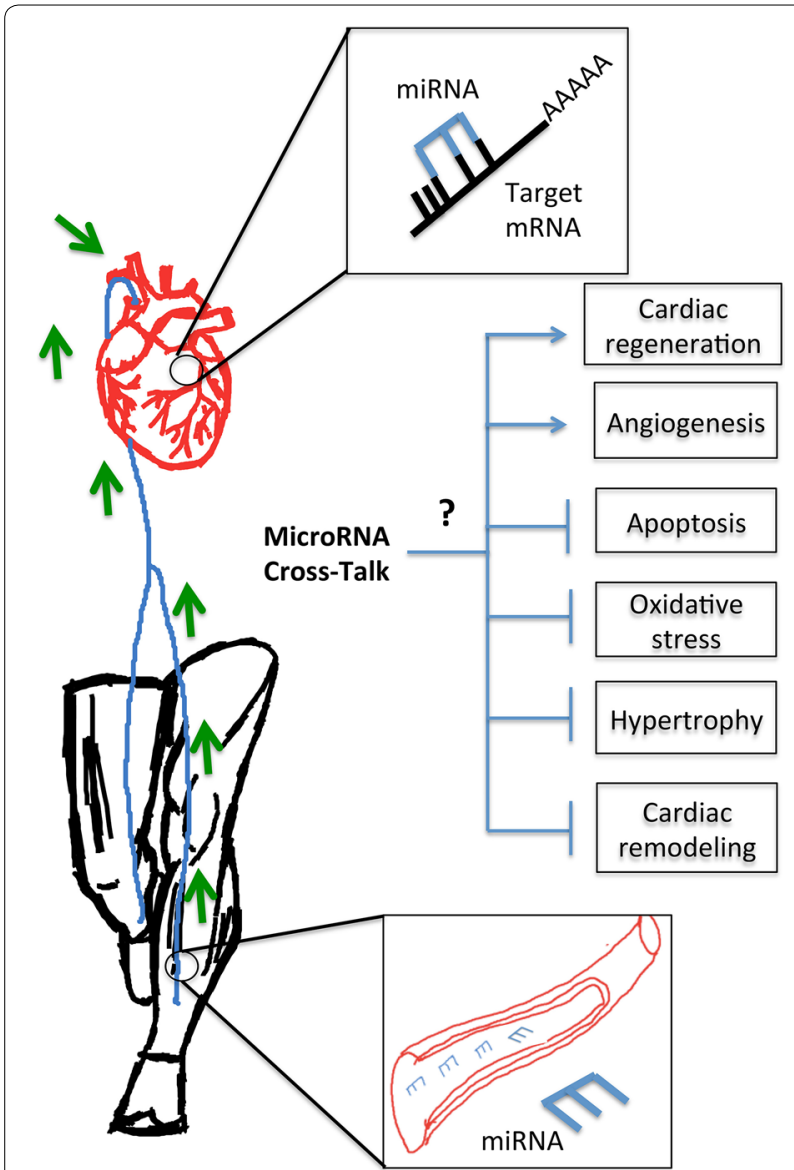

Fig. 3 Proposed cross-talk effect between exercised skeletal muscle and cardiac muscles through microRNA communication circulation (reviewed in [191]) which thereby restores the depleted level of myomiRs in the heart. While it is intriguing to speculate this cross-talk between skeletal muscle and the heart is one of the key molecular mechanisms underlying exercise induced cardioprotection (Fig. 3), available evidences support this hypothesis.

Aside from a potential 'cross-talk' effect of miRs, exercise could also have direct effects on cardiovascular miRs in diabetes. For instance, suppressed expression of miR1, miR-133 and miR-499 in the STZ-induced diabetic rat heart was associated with augmented myocardial oxidative stress and cardiac dysfunction [207]. In particular, the direct target of miR-1: protein junctin, an integral protein of ryanodine receptor (RyR) in the endoplasmic/ sarcoplasmic reticulum, was significantly elevated in the diabetic rat heart [207]. Previous studies on junctin overexpression transgenic mice demonstrated impaired calcium handling in cardiomyocytes, resulting in impaired cardiac relaxation, hypertrophy and arrhythmia [208, 209]. In addition, Wang et al. [210] has also confirmed that programmed cell death $4(\operatorname{Pdcd} 4)$, phosphofurin acidic cluster sorting protein 2 (Pacs2) and dual specificity tyrosine phosphorylation regulated kinase 2 (Dyrk2) are direct targets of miR-499. Of which, Pdcd4 and Pacs2 are involved in hydrogen peroxide-induced apoptosis in H9c2 cells, a commonly used myoblast cell line. Hence, these lines of evidence strongly suggest that dysregulation of these miRs in diabetes can have profound adverse effects on the cardiac function.

Interestingly, treating diabetic rats with antioxidants for 4 weeks not only normalized all miRs, but also improved cardiac function and ultrastructure of the diabetic heart [207]. Since exercise is able to restore antioxidant defence and normalize oxidative stress, it is possible that exercise mediated normalization of miRs could have prevented the increase of their target proteins and oxidative stress eventually suppressing apoptosis and cardiac remodelling following exercise training. However, whether exercise protects the diabetic heart through the regulation of these miRs remains to be elucidated.

\section{Exercise and $\mathrm{miR}-222$}

MiR-222 is a highly conserved member of a miR cluster which is encoded on the $\mathrm{X}$ chromosome along with miR-221 and localized in the vascular wall of the vascular smooth muscle cells [211]. Liu et al. [211] identified the key role of miR-222 in vascular smooth muscle cell proliferation through its ability to suppress the inhibition of cyclin-dependent kinase. When the ECs and progenitor endothelial cells were challenged with highglucose and AGE (diabetes-like environment) in mice, this prevented the initiation of cell cycle and the migration of EC towards VEGF stimulation, which coincided with 
the downregulation of miR-221 and -222 [212]. Further, Jiang et al. [213] demonstrated marked downregulation of miR-222 along with miR-126 and miR-92a in patients with atherosclerosis, suggesting the importance of these miRs in the evolution of cardiovascular disease.

The mechanism of action of miR-222 is through inhibition of its target proteins: $\mathrm{p} 27$, homeodomain interacting protein kinase 1 (HIPK1), HIPK2 and homeobox containing 1 (Hmbox1) [214]. In addition, Togliatto et al. [212] validated p57 as another direct target protein of miR-222. p27 and p57 are inhibitors of cell cycle, therefore upregulation of these proteins indicate cellular senescence.

Liu et al. [214] are the first to demonstrate the role of miR-222 in exercise induced cardiac protection. They showed significant upregulation of miR-222 in cardiomyocytes of mice after swimming and voluntary running regimes. They further showed that inhibition of miR-222 resulted in increased cardiomyocyte apoptosis. Interestingly, overexpression of miR-222 in mice stimulated cardiomyocyte proliferation and growth [214], which was associated with an increased $\alpha / \beta$ myosin heavy chain (MHC) ratio as well as a reduction in ANP, BNP and $\alpha$-skeletal actin mRNAs, indicating physiological cardiac adaptation. Importantly, cardiac-specific miR-222 transgenic mice were able to restore cardiac function, induce cardiomyocyte proliferation and reduce cardiac fibrosis after ischemia-reperfusion [214]. Taken together, exercise induced activation of miR-222 could be a powerful therapeutic strategy to replace the continuous loss of cardiomyocytes in individuals with diabetes.

\section{Exercise and miR-126}

MiR-126, which is one of the most extensively studied miRs, is expressed in ECs and is a potent regulator of angiogenesis. The presence of miR-126 increases the pro-angiogenic VEGF protein through the inhibition of phosphoinositide-3-kinase regulatory subunit 2 (PIK3R2) and sprout related EVH1 domain containing 1 (SPRED1), inhibitors of VEGF. Suppression of the inhibitors by miR-126 leads to activation of PI3K and Raf-1 pathways, which ultimately promote VEGF activity $[215,216]$.

The knockdown of miR-126 expression in vivo induces leaky vessels, hemorrhage and loss of vascular integrity $[215,216]$. Similarly, endothelial microparticles derived from high-glucose treated ECs showed limited endothelial cell migration and proliferation in vitro and reendothelialization in mice that had undergone carotid artery injury [217]. Moreover, a reduced expression of miR-126 has been linked to coronary artery disease, atherosclerosis and other vascular diseases [213, 217-220].

Recently we demonstrated that treatment of aortic rings from type-2 diabetic $d b / d b$ mice and high-glucose treated Human Umbilical Vein Endothelial Cells
(HUVECs) with miR-126 mimic markedly improved their impaired angiogenic potential by positively regulating VEGF protein. Increased cellular proliferation, cell migration and reduction of apoptosis were also observed as the positive outcomes of miR-126 treatment [221].

Exercise has enormous potential to be used as an approach to promote cardiac angiogenesis by stimulating the expression of miR-126 and VEGF protein. In support of this notion, a 5-day swimming regime for 10 weeks significantly increased myocardial capillary density in rats [222]. This beneficial effect was attributed to the elevation of VEGF/Raf-1/ERK and VEGF/P13 K/Akt pathways. Of note, exercise was able to repress SPRED1 and PIK3R2 proteins by upregulating miR-126 expression. Therefore, it is intriguing to postulate that exercise could be a cost-effective non-pharmacotherapy to potently upregulate angiogenic miR-126, which in turn may potentially improve coronary blood flow and function in DHD patients. More data in this context is needed to support our hypothesis.

\section{The potential for circulating miRs to determine exercise induced cardioprotection}

Alterations in the expression of cardiac-specific miR's in the early stage of diabetes may implicate the development of DHD. Rawal et al., demonstrated dysregulated expression of cardiac-specific miRs in diabetic individuals with normal EF, and further suggested that this early dysregulation together with some other clinically detectable changes may act as a catalyst for the clinical manifestations of DHD [206]. In line with this, several clinical and experimental studies have implicated the importance of miR dysregulation in cardiovascular diseases [194, 223-228]. Interestingly, miRs are released into the circulation either packed as microvesicles or bound to lipoprotein molecules where they remain stable $[229,230]$. This property of miRs gives them potential as diagnostic and prognostic biomarkers for cardiovascular diseases to identify the disease in the early stage (reviewed in [191]).

A 15-year follow-up study by Zampetaki et al. [218] revealed that the expression of miRs-15a, $-29 b,-126$ and -223 were adversely altered from the early stages of diabetes well before the development of clinical manifestations. Moreover, other studies also demonstrated the dynamic changes of miR in response to therapeutic treatment, thereby suggesting the potential role of miR as a prognostic marker for the disease [231-233].

As described above, one of the major limitations for the sustaining exercise regime is the inability to demonstrate immediate benefit. However, it is possible to demonstrate the immediate benefit of exercise through serial measurement of changes in miRs, which we consider will have a strong impact on whether individuals can sustain 
exercise in the long term. To support this notion, a recent study reported that circulating miR-1, -133 and -206 remained elevated for up to $24 \mathrm{~h}$ after running a marathon. The authors demonstrated a positive correlation between the miRs and $\mathrm{VO}_{2 \max }$ and individual anaerobic lactate threshold (VIAS). Importantly, none of these miRs were associated with cardiac injury markers such as cardiac troponin T, troponin I and pro-BNP [200].

\section{Therapeutic potential of microRNA in DHD}

Since the discovery of miRs, some two decades ago, a plethora of studies have investigated the adverse and beneficial effects of miRs in different types of diseases using diverse in vivo and in vitro models. Ultimately, select miR's have been targeted by pharmaceutical companies as potential pathways for treating diseases. For instance, miR-15, -208 and $-92 \mathrm{a}$ are currently undergoing intensive pre-clinical trials for preventing the deleterious effects associated with myocardial infarction, hypertrophic cardiomyopathy and heart failure as well as peripheral artery disease [234]. Of note, the miR-29b mimic (MRG20130-001), which attenuates pathological fibrosis, has now entered clinical trial phase I [234], while the miR-122 antagonist (SPC3649), is now in clinical trial phase II for the treatment of hepatitis C [235].

Although miR's appear as a new and exciting therapeutic strategy, only few miRs are currently undergoing clinical trials. One important reason for the cautionary approach in trialling miRs/anti-miRs in patients is that some miR's have pleiotropic effects so that inhibition or overexpression of one particular miR could have other off-target effects on non-specific organs. Therefore, it is critical to generate toxicology and safety data for miR's to compare with the current standard treatments in order to build a solid safety profile of any particular miR. Interestingly, the miR's that are currently in clinical trials are organ- or tissue-specific.

To date, there is no single miR candidate that has entered clinical trials for the treatment of DHD. As described above miR-1, $-133,-222$ and -126 are known to possess potent cardioprotection properties in animal models of diabetes. However, efficacy data, pharmacokinetics and toxicology profiles of these miRs are needed to justify clinical trials assessing these miRs in DHD. Ultimately, the research and clinical communities are enthusiastic to unravel the roles of miRs as powerful and promising interventions.

\section{Future directions and concluding remarks}

Despite significant advances in medical research and the long clinical history of anti-diabetic treatments, the incidences of diabetes-related cardiovascular complications are increasing exponentially. Yet, with no specific and effective pharmacological treatment, DHD is one of the major contributors to increased mortality rate in the current diabetic population. Results from clinical trials show that the strict control of glycemic status alone is ineffective at preventing diabetes-induced cardiac dysfunction and, in contrast, can potentially aggravate dysfunction. Surprisingly, a large number of controlled clinical trials demonstrated synergistic effects of exercise in conjunction with pharmacological treatments for managing glycaemic status in diabetes, and attenuated risks of developing cardiac dysfunction.

Although the efficacy of anti-diabetic drug regimes might be limited in ability to prevent DHD, exercise is emerging as having addictive effects for improving hyperglycaemia and insulin sensitivity by normalizing myocardial oxidative stress, lipotoxicity and systemic inflammation in diabetes. On the basis of strong evidence from molecular studies, others and we advocate exercise for ameliorating the progression of diabetes-associated cardiac dysfunction. However, as the long-term sustainability of a 'high-intensity' exercise regime has not been reported, it is reasonable to suggest that the ability of a diabetic (and often obese) population to sustain exceptionally high intensity levels of exercise might be a concern. For instance, supervised short-term high-intensity exercise has been suggested to be superior to moderateintensity exercise in improving myocardial functions $[108,120]$. However, given that the diabetic population frequently have poor exercise capacity or low $\mathrm{VO}_{2 \max }$, it may not be practical or realistic for diabetics to incorporate high-intensity exercise as lifestyle change for the prevention of DHD. This is further supported by the fact that adherence to exercise is inversely proportional to exercise intensity [236].

Yet, the emergence of miR as new and exciting biomarkers could aid clinicians in identifying those diabetic patients who are at higher risk, or predisposed to DHD at an early stage of disease. In doing so, it is hoped that a relatively modest, and sustainable, level of exercise could be prescribed to patients as an effective prophylactic strategy against DHD. Moreover, it is possible to use miRs as a marker to demonstrate the immediate benefit of exercise on heart, which is currently impossible by other means.

Based on our current understanding of the benefits of exercise on cardiac function in diabetes, there is a sense of urgency that future studies focus on the optimal intensity of exercise in diabetic patients, in the very early stages of the disease, that is both sustainable longterm as a lifestyle adaptation, but also effectively protects against the onset of DHD because, ultimately, DHD is a chronic condition that will require life-long management for ensuring a successful outcome. 


\section{Abbreviations}

T2DM: type-2 diabetes mellitus; FHS: Framingham Heart Study; CDH: coronary heart disease; DMD: diabetic heart disease; NIH: National Institute of Health; PKC: protein kinase-C; AGEs: advanced glycation end products; NADPH: nicotinamide adenine dinucleotide phosphate; GSH: reduced glutathione; DAG: diacylglycerol; G3P: glycerol-3-phosphate; NF-KB: nuclear factor kappa-lightchain-enhancer of activated B cell; eNOS: endothelial nitric oxide synthase; ROS: reactive oxygen species; RAGE: AGE receptor; ECs: endothelial cells; GICN6-P: glucosamine-6-phosphate; GFAT: glutamine:fructose-6-phosphate amidotransferase; UDP: uridine diphosphate; O-GlcNAc: O-linked N-acetylglucosamine transferase; IRS-1: insulin receptor substrate-1; PI3K: phosphoinositide-3 kinase; PDK1: phosphoinositide-dependent kinase 1; Akt: protein kinase B; aPKC: atypical protein kinase C; GLUT: glucose transporter; MAPK: mitogenactivated protein kinase; JNK: C-Jun-N-terminal kinase; ERK: extracellular signal-regulated kinase; FFA: free fatty acid; TNF- $a$ : tumour necrosis factoralpha; IL: interleukin; NFKB: nuclear factor kappa B; IKKB: I-kappaB kinase beta; SOCS: suppressor of cytokine-signalling; UKPDS: United Kingdom Prospective Diabetes Study; ADVANCE: action in diabetes and vascular disease; ACCORD: action to control cardiovascular risk in diabetes; VADT: Veterans affairs diabetes trial; ADA: American Diabetes Association; DPP: diabetes prevention program; $\mathrm{VO}_{2 \text { max }}$ : maximum oxygen consumption; LVEF: left ventricular ejection fraction; miR: microRNA; ${ }^{1} \mathrm{H}-\mathrm{MRS}$ : proton magnetic resonance spectroscopy; POVPC: 1-palmitoyl-2-(-5-oxovaleroyl)-sn-glycero-3-phosphorylcholine; PGPC: 1-palmitoyl-2-glutaroyl-sn-glycero-3-phosphorylcholine; LDL: low-density lipoprotein; MDA: malondialdehyde; $\mathrm{HbA}_{1}$ : glycated haemoglobin; SOD: superoxide dismutase; MnSOD: mitochondrial SOD; Nrf2: nuclear erythroid 2 p45-related factor 2; G6pd: glucose-6-phosphatedehydrogenase; Nqo 1: NAD(P)H-quinone oxydase-1; Gsr: glutathione reductase; Gclc: $\Upsilon$-glutamyl cysteine ligase-catalytic; GcIm: $\Upsilon$-glytamyl cysteine ligase-modulatory; IMA: ischemia-modified albumin; hs-CRP: high-sensitive C-reactive protein; HOMAIR: homeostatic model assessment-insulin resistance; LKB1: liver-kinase B1; AMPK: adenosine monophosphate-activated protein kinase; APPL1: adaptor protein phosphotyrosine interaction $\mathrm{PH}$ domain and leucine zipper containing 1; PGC1-a: peroxisome proliferator-activated receptor gamma coactivator 1-alpha; ERRa: estrogen related receptor- a; VEGF: vascular growth factor; PDGF: platelet-derived growth factor; CTGF: connective tissue growth factor; Bim: B cell lymphoma-2 like 11; Bmf: B-cell lymphoma-2 modifying factor; Anp: atrial natriuretic peptide; Bnp: brain natriuretic peptide; SGK1: serum and glycocorticoid-regulated kinase 1; IGF1R: insulin-like growth factor 1 receptor; MMP-9: matrix metallopeptidase-9; JCN: junctin; RyR: ryanodine receptor; Pdcd4: programmed cell death 4; Pacs2: phosphofurin acidic cluster sorting protein 2; Dyrk2: dual specificity tyrosine phosphorylation regulated kinase 2; MHC: myosin heavy chain; HIPK: homeodomain interacting protein kinase; Hmbox1: homeobox containing 1; PIK3R2: phosphoinositide-3-kinase regulatory subunit 2; SPRED1: sprout related EVH1 domain containing 1; HUVECS: human Umbilical Vein Endothelial Cells; VIAS: individual anaerobic lactate threshold.

\section{Authors' contributions}

JKS contributed to conception and design and wrote the first draft the review; JTP critically reviewed and wrote the second draft of the manuscript; DOS and RK contributed to conception and design of the article and critically reviewed the drafts of the manuscript. All authors read and approved the final manuscript.

\section{Author details}

1 Department of Physiology, HeartOtago, University of Otago, 270, Great King Street, Dunedin 9010, New Zealand. ${ }^{2}$ Department of Cardiac Physiology, National Cerebral and Cardiovascular Center Research Institute, Suita, Osaka, Japan. ${ }^{3}$ Biomedicine Discovery Institute and Department of Physiology, Monash University, Clayton, Australia.

\section{Acknowledgements}

We greatly acknowledge the advice and suggestions of Dr. Aram Ahmed Babakr relating to current clinical practices.

\section{Competing interests}

The authors declare that they have no competing interests.

\section{Funding}

This work was supported by project grants from Heart Foundation New Zealand, Otago Medical Research Foundation (AG307), University of Otago Research Grant, Lottery Health Board, New Zealand and Intramural Research Fund (27-2-1) from the National Cerebral and Cardiovascular Center, Japan. Jason Lew is supported by the University of Otago Doctoral Scholarship and the Department of Physiology, University of Otago.

Received: 10 November 2016 Accepted: 17 December 2016 Published online: 13 January 2017

\section{References}

1. International diabetes federation: IDF DIABETES ATLAS Sixth edition. KEY FINDINGS 2014. http://www.idf.org/diabetesatlas/update-2014. Accessed 4 Dec 2016.

2. American Heart Association: Cardiovascular Disease \& Diabetes. http:// www.heart.org/HEARTORG/Conditions/Diabetes/WhyDiabetesMatters/Cardiovascular-Disease-Diabetes_UCM_313865_Article.jsp/-. ViN43CTIfFI. Accessed 4 Dec 2016.

3. Wright JJ, Kim J, Buchanan J, Boudina S, Sena S, Bakirtzi K, Ilkun O, Theobald HA, Cooksey RC, Kandror KV, et al. Mechanisms for increased myocardial fatty acid utilization following short-term high-fat feeding. Cardiovasc Res. 2009;82(2):351-60.

4. Cook SA, Varela-Carver A, Mongillo M, Kleinert C, Khan MT, Leccisotti L, Strickland N, Matsui T, Das S, Rosenzweig A, et al. Abnormal myocardial insulin signalling in type 2 diabetes and left-ventricular dysfunction. Eur Heart J. 2010;31(1):100-11.

5. Shimizu I, Minamino T, Toko H, Okada S, Ikeda H, Yasuda N, Tateno K, Moriya J, Yokoyama M, Nojima A, et al. Excessive cardiac insulin signaling exacerbates systolic dysfunction induced by pressure overload in rodents. J Clin Investig. 2010;120(5):1506-14.

6. Okere IC, Chandler MP, McElfresh TA, Rennison JH, Sharov V, Sabbah HN, Tserng KY, Hoit BD, Ernsberger P, Young ME, et al. Differential effects of saturated and unsaturated fatty acid diets on cardiomyocyte apoptosis, adipose distribution, and serum leptin. Am J Physiol Heart Circ Physiol. 2006;291(1):H38-44.

7. Chavez JA, Knotts TA, Wang LP, Li G, Dobrowsky RT, Florant GL, Summers SA. A role for ceramide, but not diacylglycerol, in the antagonism of insulin signal transduction by saturated fatty acids. J Biol Chem. 2003;278(12):10297-303.

8. Hagemann D, Bohlender J, Hoch B, Krause EG, Karczewski P. Expression of $\mathrm{Ca}^{2+} /$ calmodulin-dependent protein kinase II delta-subunit isoforms in rats with hypertensive cardiac hypertrophy. Mol Cell Biochem. 2001;220(1-2):69-76.

9. Bradley TJ, Slorach C, Mahmud FH, Dunger DB, Deanfield J, Deda L, Elia Y, Har RL, Hui W, Moineddin R, et al. Early changes in cardiovascular structure and function in adolescents with type 1 diabetes. Cardiovasc Diabetol. 2016;15:31.

10. Kannel WB, McGee DL. Diabetes and cardiovascular risk factors: the Framingham study. Circulation. 1979;59(1):8-13.

11. Fox CS, Sullivan L, D'Agostino RB Sr, Wilson PW, Framingham Heart S. The significant effect of diabetes duration on coronary heart disease mortality: the Framingham Heart Study. Diabetes Care. 2004;27(3):704-8.

12. Preis SR, Hwang SJ, Coady S, Pencina MJ, D'Agostino RB Sr, Savage PJ, Levy D, Fox CS. Trends in all-cause and cardiovascular disease mortality among women and men with and without diabetes mellitus in the Framingham Heart Study, 1950 to 2005. Circulation. 2009;119(13):1728-35.

13. Asmal AC, Leary WP, Thandroyen F. Diabetic heart disease. South Afr Med J. 1980;57(19):788-90.

14. National Institute of Health: what is diabetic heart disease. https://www. nhlbi.nih.gov/health/health-topics/topics/dhd. Accessed 4 Dec 2016.

15. Marwick TH. Diabetic heart disease. Heart. 2006;92(3):296-300.

16. Chen V, lanuzzo CD, Fong BC, Spitzer JJ. The effects of acute and chronic diabetes on myocardial metabolism in rats. Diabetes. 1984;33(11):1078-84. 
17. Garvey WT, Hardin D, Juhaszova M, Dominguez JH. Effects of diabetes on myocardial glucose transport system in rats: implications for diabetic cardiomyopathy. Am J Physiol. 1993;264(3 Pt 2):H837-44.

18. Bonora E, Formentini G, Calcaterra F, Lombardi S, Marini F, Zenari L, Saggiani F, Poli M, Perbellini S, Raffaelli A, et al. HOMA-estimated insulin resistance is an independent predictor of cardiovascular disease in type 2 diabetic subjects: prospective data from the Verona Diabetes Complications Study. Diabetes Care. 2002;25(7):1135-41.

19. Boudina S, Bugger H, Sena S, O'Neill BT, Zaha VG, Ilkun O, Wright JJ, Mazumder PK, Palfreyman E, Tidwell TJ, et al. Contribution of impaired myocardial insulin signaling to mitochondrial dysfunction and oxidative stress in the heart. Circulation. 2009;1 19(9):1272-83.

20. Buchanan J, Mazumder PK, Hu P, Chakrabarti G, Roberts MW, Yun UJ, Cooksey RC, Litwin SE, Abel ED. Reduced cardiac efficiency and altered substrate metabolism precedes the onset of hyperglycemia and contractile dysfunction in two mouse models of insulin resistance and obesity. Endocrinology. 2005;146(12):5341-9.

21. Peterson $L R$, Herrero $P$, Schechtman $K B$, Racette $S B$, Waggoner $A D$, Kisrieva-Ware Z, Dence C, Klein S, Marsala J, Meyer T, et al. Effect of obesity and insulin resistance on myocardial substrate metabolism and efficiency in young women. Circulation. 2004;109(18):2191-6.

22. Aguilar H, Fricovsky E, Ihm S, Schimke M, Maya-Ramos L, Aroonsakool N, Ceballos G, Dillmann W, Villarreal F, Ramirez-Sanchez I. Role for high-glucose-induced protein O-GlcNAcylation in stimulating cardiac fibroblast collagen synthesis. Am J Physiol Cell Physiol. 2014;306(9):C794-804.

23. Stratton IM, Adler Al, Neil HA, Matthews DR, Manley SE, Cull CA, Hadden D, Turner RC, Holman RR. Association of glycaemia with macrovascular and microvascular complications of type 2 diabetes (UKPDS 35): prospective observational study. BMJ. 2000;321(7258):405-12.

24. Nielsen R, Norrelund H, Kampmann U, Botker HE, Moller N, Wiggers H. Effect of acute hyperglycemia on left ventricular contractile function in diabetic patients with and without heart failure: two randomized crossover studies. PLoS ONE. 2013;8(1):e53247.

25. Waddingham MT, Edgley AJ, Tsuchimochi H, Kelly DJ, Shirai M, Pearson JT. Contractile apparatus dysfunction early in the pathophysiology of diabetic cardiomyopathy. World J Diabetes. 2015;6(7):943-60.

26. Du XL, Edelstein D, Rossetti L, Fantus IG, Goldberg H, Ziyadeh F, Wu J, Brownlee M. Hyperglycemia-induced mitochondrial superoxide overproduction activates the hexosamine pathway and induces plasminogen activator inhibitor-1 expression by increasing Sp1 glycosylation. Proc Natl Acad Sci USA. 2000;97(22):12222-6.

27. Nishikawa T, Edelstein D, Du XL, Yamagishi S, Matsumura T, Kaneda Y, Yorek MA, Beebe D, Oates PJ, Hammes HP, et al. Normalizing mitochondrial superoxide production blocks three pathways of hyperglycaemic damage. Nature. 2000;404(6779):787-90.

28. Gonzalez RG, Barnett P, Aguayo J, Cheng HM, Chylack LT Jr. Direct measurement of polyol pathway activity in the ocular lens. Diabetes. 1984:33(2):196-9.

29. Bravi MC, Pietrangeli P, Laurenti O, Basili S, Cassone-Faldetta M, Ferri C, De Mattia G. Polyol pathway activation and glutathione redox status in non-insulin-dependent diabetic patients. Metab Clin Exp. 1997;46(10):1194-8.

30. De Mattia G, Laurenti O, Bravi C, Ghiselli A, luliano L, Balsano F. Effect of aldose reductase inhibition on glutathione redox status in erythrocytes of diabetic patients. Metab Clin Exp. 1994;43(8):965-8.

31. Ramasamy R, Oates PJ, Schaefer S. Aldose reductase inhibition protects diabetic and nondiabetic rat hearts from ischemic injury. Diabetes. 1997:46(2):292-300

32. Johnson BF, Nesto RW, Pfeifer MA, Slater WR, Vinik Al, Chyun DA, Law G, Wackers FJ, Young LH. Cardiac abnormalities in diabetic patients with neuropathy: effects of aldose reductase inhibitor administration. Diabetes Care. 2004;27(2):448-54.

33. Xia P, Inoguchi T, Kern TS, Engerman RL, Oates PJ, King GL. Characterization of the mechanism for the chronic activation of diacylglycerolprotein kinase $C$ pathway in diabetes and hypergalactosemia. Diabetes. 1994:43(9):1122-9.

34. Igarashi M, Wakasaki H, Takahara N, Ishii H, Jiang ZY, Yamauchi T, Kuboki K, Meier M, Rhodes CJ, King GL. Glucose or diabetes activates p38 mitogen-activated protein kinase via different pathways. J Clin Investig. 1999;103(2):185-95.
35. Way KJ, Isshiki K, Suzuma K, Yokota T, Zvagelsky D, Schoen FJ, Sandusky GE, Pechous PA, Vlahos CJ, Wakasaki H, et al. Expression of connective tissue growth factor is increased in injured myocardium associated with protein kinase $\mathrm{C}$ beta2 activation and diabetes. Diabetes. 2002;51(9):2709-18.

36. Yamaguchi H, Igarashi M, Hirata A, Sugae $N$, Tsuchiya H, Jimbu Y, Tominaga $\mathrm{M}$, Kato T. Altered PDGF-BB-induced p38 MAP kinase activation in diabetic vascular smooth muscle cells: roles of protein kinase C-delta. Arterioscler Thromb Vasc Biol. 2004;24(11):2095-101.

37. Hattori Y, Hattori S, Sato N, Kasai K. High-glucose-induced nuclear factor kappaB activation in vascular smooth muscle cells. Cardiovasc Res. 2000;46(1):188-97.

38. Tabit CE, Shenouda SM, Holbrook M, Fetterman JL, Kiani S, Frame AA, Kluge MA, Held A, Dohadwala MM, Gokce N, et al. Protein kinase C-beta contributes to impaired endothelial insulin signaling in humans with diabetes mellitus. Circulation. 2013;127(1):86-95.

39. Chen F, Yu Y, Haigh S, Johnson J, Lucas R, Stepp DW, Fulton DJ. Regulation of NADPH oxidase 5 by protein kinase $C$ isoforms. PLoS ONE. 2014;9(2):e88405.

40. Inoguchi T, Li P, Umeda F, Yu HY, Kakimoto M, Imamura M, Aoki T, Etoh T, Hashimoto T, Naruse M, et al. High glucose level and free fatty acid stimulate reactive oxygen species production through protein kinase C-dependent activation of $\mathrm{NAD}(\mathrm{P}) \mathrm{H}$ oxidase in cultured vascular cells. Diabetes. 2000;49(11):1939-45.

41. Wakasaki H, Koya D, Schoen FJ, Jirousek MR, Ways DK, Hoit BD, Walsh RA, King GL. Targeted overexpression of protein kinase $C$ beta2 isoform in myocardium causes cardiomyopathy. Proc Natl Acad Sci USA. 1997;94(17):9320-5.

42. Brownlee M. Biochemistry and molecular cell biology of diabetic complications. Nature. 2001;414(6865):813-20.

43. Airaksinen KE, Salmela PI, Linnaluoto MK, Ikaheimo MJ, Ahola K, Ryhanen LJ. Diminished arterial elasticity in diabetes: association with fluorescent advanced glycosylation end products in collagen. Cardiovasc Res. 1993;27(6):942-5.

44. Candido R, Forbes JM, Thomas MC, Thallas V, Dean RG, Burns WC, Tikellis C, Ritchie RH, Twigg SM, Cooper ME, et al. A breaker of advanced glycation end products attenuates diabetes-induced myocardial structural changes. Circ Res. 2003;92(7):785-92.

45. Tsilibary EC, Charonis AS, Reger LA, Wohlhueter RM, Furcht LT. The effect of nonenzymatic glucosylation on the binding of the main noncollagenous NC1 domain to type IV collagen. J Biol Chem. 1988;263(9):4302-8.

46. Sims TJ, Rasmussen LM, Oxlund H, Bailey AJ. The role of glycation cross-links in diabetic vascular stiffening. Diabetologia. 1996;39(8):946-51.

47. Basta G, Lazzerini G, Massaro M, Simoncini T, Tanganelli P, Fu C, Kislinger T, Stern DM, Schmidt AM, De Caterina R. Advanced glycation end products activate endothelium through signal-transduction receptor RAGE: a mechanism for amplification of inflammatory responses. Circulation. 2002;105(7):816-22.

48. Li J, Schmidt AM. Characterization and functional analysis of the promoter of RAGE, the receptor for advanced glycation end products. J Biol Chem. 1997;272(26):16498-506.

49. Kislinger T, Tanji N, Wendt T, Qu W, Lu Y, Ferran LJ Jr, Taguchi A, Olson K, Bucciarelli L, Goova M, et al. Receptor for advanced glycation end products mediates inflammation and enhanced expression of tissue factor in vasculature of diabetic apolipoprotein E-null mice. Arterioscler Thromb Vasc Biol. 2001;21 (6):905-10.

50. Bucciarelli LG, Wendt T, Qu W, Lu Y, Lalla E, Rong LL, Goova MT, Moser B, Kislinger T, Lee DC, et al. RAGE blockade stabilizes established atherosclerosis in diabetic apolipoprotein E-null mice. Circulation. 2002;106(22):2827-35.

51. Quehenberger P, Bierhaus A, Fasching P, Muellner C, Klevesath M, Hong M, Stier G, Sattler M, Schleicher E, Speiser W, et al. Endothelin 1 transcription is controlled by nuclear factor-kappaB in AGE-stimulated cultured endothelial cells. Diabetes. 2000;49(9):1561-70.

52. Zitman-Gal T, Golan E, Green J, Bernheim J, Benchetrit S. Vitamin D receptor activation in a diabetic-like environment: potential role in the activity of the endothelial pro-inflammatory and thioredoxin pathways. J Steroid Biochem Mol Biol. 2012;132(1-2):1-7. 
53. Zitman-Gal T, Green J, Korzets Z, Bernheim J, Benchetrit S. Kruppel-like factors in an endothelial and vascular smooth muscle cell coculture model: impact of a diabetic environment and vitamin D. Vitro Cell Dev Biol Anim. 2015;51(5):470-8.

54. Zitman-Gal T, Green J, Pasmanik-Chor M, Golan E, Bernheim J, Benchetrit S. Vitamin D manipulates miR-181c, miR-20b and miR-15a in human umbilical vein endothelial cells exposed to a diabetic-like environment. Cardiovasc Diabetol. 2014;13:8.

55. Raposeiras-Roubin S, Rodino-Janeiro BK, Grigorian-Shamagian L, Moure-Gonzalez M, Seoane-Blanco A, Varela-Roman A, Almenar-Bonet L, Alvarez E, Gonzalez-Juanatey JR. Relation of soluble receptor for advanced glycation end products to predict mortality in patients with chronic heart failure independently of Seattle Heart Failure Score. Am J Cardiol. 2011;107(6):938-44

56. Sarkar P, Kar K, Mondal MC, Chakraborty I, Kar M. Elevated level of carbonyl compounds correlates with insulin resistance in type 2 diabetes. Ann Acad Med Singap. 2010;39(12):904-9.

57. Buse MG. Hexosamines, insulin resistance, and the complications of diabetes: current status. Am J Physiol Endocrinol Metab. 2006;290(1):E1-8.

58. Housley MP, Rodgers JT, Udeshi ND, Kelly TJ, Shabanowitz J, Hunt DF, Puigserver $\mathrm{P}$, Hart GW. O-GIcNAc regulates FoxO activation in response to glucose. J Biol Chem. 2008;283(24):16283-92.

59. Erickson JR, Pereira L, Wang L, Han G, Ferguson A, Dao K, Copeland RJ, Despa F, Hart GW, Ripplinger CM, et al. Diabetic hyperglycaemia activates CaMKII and arrhythmias by O-linked glycosylation. Nature. 2013;502(7471):372-6.

60. Vosseller K, Wells L, Lane MD, Hart GW. Elevated nucleocytoplasmic glycosylation by O-GICNAc results in insulin resistance associated with defects in Akt activation in 3T3-L1 adipocytes. Proc Natl Acad Sci USA 2002;99(8):5313-8.

61. Huynh K, Bernardo BC, McMullen JR, Ritchie RH. Diabetic cardiomyopathy: mechanisms and new treatment strategies targeting antioxidant signaling pathways. Pharmacol Ther. 2014;142(3):375-415.

62. Lunde IG, Aronsen JM, Kvaloy H, Qvigstad E, Sjaastad I, Tonnessen T, Christensen G, Gronning-Wang LM, Carlson CR. Cardiac O-GICNAc signaling is increased in hypertrophy and heart failure. Physiol Genomics. 2012;44(2):162-72.

63. Lima WV, Giachini FR, Carneiro FS, Carneiro ZN, Saleh MA, Pollock DM, Fortes ZB, Carvalho MH, Ergul A, Webb RC, et al. O-GlcNAcylation contributes to augmented vascular reactivity induced by endothelin 1 . Hypertension. 2010;55(1):180-8.

64. Fischer $Y$, Thomas J, Sevilla L, Munoz P, Becker C, Holman G, Kozka IJ, Palacin $M$, Testar $X$, Kammermeier $H$, et al. Insulin-induced recruitment of glucose transporter 4 (GLUT4) and GLUT1 in isolated rat cardiac myocytes. Evidence of the existence of different intracellular GLUT4 vesicle populations. J Biol Chem. 1997;272(11):7085-92.

65. Martin SS, Haruta T, Morris AJ, Klippel A, Williams LT, Olefsky JM. Activated phosphatidylinositol 3-kinase is sufficient to mediate actin rearrangement and GLUT4 translocation in 3T3-L1 adipocytes. J Biol Chem. 1996;271(30):17605-8.

66. Zeng G, Nystrom FH, Ravichandran LV, Cong LN, Kirby M, Mostowski H, Quon MJ. Roles for insulin receptor, PI3-kinase, and Akt in insulin-signaling pathways related to production of nitric oxide in human vascular endothelial cells. Circulation. 2000;101(13):1539-45.

67. Hermann C, Assmus B, Urbich C, Zeiher AM, Dimmeler S. Insulinmediated stimulation of protein kinase Akt: a potent survival signaling cascade for endothelial cells. Arterioscler Thromb Vasc Biol. 2000;20(2):402-9

68. Wu YT, Tan HL, Huang Q, Ong CN, Shen HM. Activation of the PI3K-AktmTOR signaling pathway promotes necrotic cell death via suppression of autophagy. Autophagy. 2009;5(6):824-34.

69. Taniguchi CM, Kondo T, Sajan M, Luo J, Bronson R, Asano T, Farese R, Cantley LC, Kahn CR. Divergent regulation of hepatic glucose and lipid metabolism by phosphoinositide 3-kinase via Akt and PKClambda/zeta. Cell Metab. 2006;3(5):343-53.

70. Saltiel AR, Kahn CR. Insulin signalling and the regulation of glucose and lipid metabolism. Nature. 2001;414(6865):799-806.

71. Zarubin T, Han J. Activation and signaling of the p38 MAP kinase pathway. Cell Res. 2005;15(1):11-8.

72. Mendoza MC, Er EE, Blenis J. The Ras-ERK and PI3K-mTOR pathways: cross-talk and compensation. Trends Biochem Sci. 2011;36(6):320-8.
73. Muniyappa R, Montagnani M, Koh KK, Quon MJ. Cardiovascular actions of insulin. Endocr Rev. 2007;28(5):463-91.

74. Jiang ZY, Lin YW, Clemont A, Feener EP, Hein KD, Igarashi M, Yamauchi T, White MF, King GL. Characterization of selective resistance to insulin signaling in the vasculature of obese Zucker (fa/fa) rats. J Clin Investig. 1999;104(4):447-57

75. Cusi K, Maezono K, Osman A, Pendergrass M, Patti ME, Pratipanawatr T, DeFronzo RA, Kahn CR, Mandarino LJ. Insulin resistance differentially affects the PI 3-kinase- and MAP kinase-mediated signaling in human muscle. J Clin Investig. 2000;105(3):311-20.

76. De Nigris V, Pujadas G, La Sala L, Testa R, Genovese S, Ceriello A. Shortterm high glucose exposure impairs insulin signaling in endothelial cells. Cardiovas Diabetol. 2015;14:114.

77. Felber JP, Ferrannini E, Golay A, Meyer HU, Theibaud D, Curchod B,

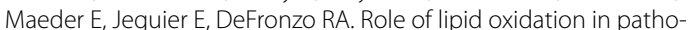
genesis of insulin resistance of obesity and type II diabetes. Diabetes. 1987;36(11):1341-50.

78. Roden M, Price TB, Perseghin G, Petersen KF, Rothman DL, Cline GW Shulman GI. Mechanism of free fatty acid-induced insulin resistance in humans. J Clin Investig. 1996;97(12):2859-65.

79. Mazumder PK, O'Neill BT, Roberts MW, Buchanan J, Yun UJ, Cooksey RC, Boudina S, Abel ED. Impaired cardiac efficiency and increased fatty acid oxidation in insulin-resistant ob/ob mouse hearts. Diabetes. 2004;53(9):2366-74

80. Hasegawa S, Yamamoto K, Sakata Y, Takeda Y, Kajimoto K, Kanai Y, Hori M, Hatazawa J. Effects of cardiac energy efficiency in diastolic heart failure: assessment with positron emission tomography with 11C-acetate. Hypertens Res. 2008;31(6):1157-62.

81. Witte KK, Levy WC, Lindsay KA, Clark AL. Biomechanical efficiency is impaired in patients with chronic heart failure. Eur J Heart Fail. 2007;9(8):834-8.

82. Du X, Edelstein D, Obici S, Higham N, Zou MH, Brownlee M. Insulin resistance reduces arterial prostacyclin synthase and eNOS activities by increasing endothelial fatty acid oxidation. J Clin Investig. 2006;116(4):1071-80.

83. Archuleta TL, Lemieux AM, Saengsirisuwan $V$, Teachey MK, Lindborg KA, Kim JS, Henriksen EJ. Oxidant stress-induced loss of IRS-1 and IRS-2 proteins in rat skeletal muscle: role of p38 MAPK. Free Radic Biol Med. 2009;47(10):1486-93.

84. Abel ED, O'Shea KM, Ramasamy R. Insulin resistance: metabolic mechanisms and consequences in the heart. Arterioscler Thromb Vasc Biol. 2012;32(9):2068-76.

85. Witteles RM, Fowler MB. Insulin-resistant cardiomyopathy clinical evidence, mechanisms, and treatment options. J Am Coll Cardiol. 2008;51(2):93-102.

86. Mariappan N, Elks CM, Sriramula S, Guggilam A, Liu Z, Borkhsenious $\mathrm{O}$, Francis J. NF-kappaB-induced oxidative stress contributes to mitochondrial and cardiac dysfunction in type II diabetes. Cardiovasc Res. 2010;85(3):473-83.

87. Rui L, Aguirre V, Kim JK, Shulman Gl, Lee A, Corbould A, Dunaif A, White MF. Insulin/IGF-1 and TNF-alpha stimulate phosphorylation of IRS-1 at inhibitory Ser307 via distinct pathways. J Clin Investig. 2001:107(2):181-9.

88. de Alvaro C, Teruel T, Hernandez R, Lorenzo M. Tumor necrosis factor alpha produces insulin resistance in skeletal muscle by activation of inhibitor kappaB kinase in a p38 MAPK-dependent manner. J Biol Chem. 2004:279(17):17070-8.

89. Emanuelli B, Peraldi P, Filloux C, Chavey C, Freidinger K, Hilton DJ, Hotamisligil GS, Van Obberghen E. SOCS-3 inhibits insulin signaling and is up-regulated in response to tumor necrosis factor-alpha in the adipose tissue of obese mice. J Biol Chem. 2001;276(51):47944-9.

90. Campbell JS, Prichard L, Schaper F, Schmitz J, Stephenson-Famy A, Rosenfeld ME, Argast GM, Heinrich PC, Fausto N. Expression of suppressors of cytokine signaling during liver regeneration. J Clin Investig. 2001;107(10):1285-92.

91. Rui L, Yuan M, Frantz D, Shoelson S, White MF. SOCS-1 and SOCS-3 block insulin signaling by ubiquitin-mediated degradation of IRS1 and IRS2. J Biol Chem. 2002;277(44):42394-8

92. Ueki K, Kondo T, Kahn CR. Suppressor of cytokine signaling 1 (SOCS-1) and SOCS-3 cause insulin resistance through inhibition of tyrosine 
phosphorylation of insulin receptor substrate proteins by discrete mechanisms. Mol Cell Biol. 2004;24(12):5434-46.

93. American Diabetes Association: Can Diabetes Pills Help Me? http:// www.diabetes.org/living-with-diabetes/treatment-and-care/medication/oral-medications/can-diabetes-pills-help-me.html. Accessed 4 Dec 2016.

94. American Heart Association: Diabetes Medications. http://www.heart. org/HEARTORG/Conditions/Diabetes/PreventionTreatmentofDiabetes/ Diabetes-Medications_UCM_313870_Article.jsp-.VsZleiQTHFI. Accessed 4 Dec 2016.

95. National Institute of Health: How Is Diabetic Heart Disease Treated? http://www.nhlbi.nih.gov/health/health-topics/topics/dhd/treatment. Accessed 4 Dec 2016.

96. UK Prospective Diabetes Study (UKPDS) Group. Intensive blood-glucose control with sulphonylureas or insulin compared with conventional treatment and risk of complications in patients with type 2 diabetes (UKPDS 33). Lancet. 1998;352(9131):837-53.

97. Group AC, Patel A, MacMahon S, Chalmers J, Neal B, Billot L, Woodward M, Marre M, Cooper M, Glasziou P, et al. Intensive blood glucose control and vascular outcomes in patients with type 2 diabetes. N Engl J Med. 2008;358(24):2560-72.

98. Action to Control Cardiovascular Risk in Diabetes Study G, Gerstein HC, Miller ME, Byington RP, Goff DC Jr, Bigger JT, Buse JB, Cushman WC, Genuth S, Ismail-Beigi F, et al. Effects of intensive glucose lowering in type 2 diabetes. N Engl J Med. 2008;358(24):2545-59.

99. Duckworth W, Abraira C, Moritz T, Reda D, Emanuele N, Reaven PD, Zieve FJ, Marks J, Davis SN, Hayward R, et al. Glucose control and vascular complications in veterans with type 2 diabetes. $N$ Engl I Med. 2009;360(2):129-39.

100. Udell JA, Cavender MA, Bhatt DL, Chatterjee S, Farkouh ME, Scirica BM. Glucose-lowering drugs or strategies and cardiovascular outcomes in patients with or at risk for type 2 diabetes: a metaanalysis of randomised controlled trials. Lancet Diabetes Endocrinol. 2015;3(5):356-66.

101. Tanasescu M, Leitzmann MF, Rimm EB, Hu FB. Physical activity in relation to cardiovascular disease and total mortality among men with type 2 diabetes. Circulation. 2003;107(19):2435-9.

102. Gregg EW, Gerzoff RB, Caspersen CJ, Williamson DF, Narayan KM. Relationship of walking to mortality among US adults with diabetes. Arch Intern Med. 2003;163(12):1440-7.

103. Hu FB, Stampfer MJ, Solomon C, Liu S, Colditz GA, Speizer FE, Willett WC, Manson JE. Physical activity and risk for cardiovascular events in diabetic women. Ann Intern Med. 2001;134(2):96-105.

104. Thent ZC, Das S, Henry LJ. Role of exercise in the management of diabetes mellitus: the global scenario. PLoS ONE. 2013;8(11):e80436.

105. Cassidy S, Thoma C, Hallsworth K, Parikh J, Hollingsworth KG, Taylor R, Jakovljevic DG, Trenell MI. High intensity intermittent exercise improves cardiac structure and function and reduces liver fat in patients with type 2 diabetes: a randomised controlled trial. Diabetologia. 2016;59(1):56-66.

106. Brassard P, Legault S, Garneau C, Bogaty P, Dumesnil JG, Poirier P. Normalization of diastolic dysfunction in type 2 diabetics after exercise training. Med Sci Sports Exerc. 2007;39(11):1896-901.

107. Goulopoulou S, Baynard T, Franklin RM, Fernhall B, Carhart R Jr, Weinstock R, Kanaley JA. Exercise training improves cardiovascular autonomic modulation in response to glucose ingestion in obese adults with and without type 2 diabetes mellitus. Metab Clin Exp. 2010;59(6):901-10.

108. Tjonna AE, Lee SJ, Rognmo O, Stolen TO, Bye A, Haram PM, Loennechen JP, Al-Share QY, Skogvoll E, Slordahl SA, et al. Aerobic interval training versus continuous moderate exercise as a treatment for the metabolic syndrome: a pilot study. Circulation. 2008;118(4):346-54.

109. Hollekim-Strand SM, Bjorgaas MR, Albrektsen G, Tjonna AE, Wisloff $\mathrm{U}$, Ingul CB. High-intensity interval exercise effectively improves cardiac function in patients with type 2 diabetes mellitus and diastolic dysfunction: a randomized controlled trial. J Am Coll Cardiol. 2014;64(16):1758-60.

110. American Diabetes Association: Aerobic Exercise. http://www.diabetes. org/food-and-fitness/fitness/types-of-activity/what-we-recommend. html. Accessed 4 Dec 2016.
111. Diabetes Prevention Program (DPP). http://www.niddk.nih.gov/aboutniddk/research-areas/diabetes/diabetes-prevention-program-dpp/ Pages/default.aspx. Accessed 4 Dec 2016.

112. Hafstad AD, Boardman NT, Lund J, Hagve M, Khalid AM, Wisloff U, Larsen TS, Aasum E. High intensity interval training alters substrate utilization and reduces oxygen consumption in the heart. J Appl Physiol. 2011;111(5):1235-41.

113. Lee $S$, Park Y, Zhang C. Exercise training prevents coronary endothelial dysfunction in type 2 diabetic mice. Am J Biomed Sci. 2011;3(4):241-52.

114. Dunstan DW, Daly RM, Owen N, Jolley D, De Courten M, Shaw J, Zimmet P. High-intensity resistance training improves glycemic control in older patients with type 2 diabetes. Diabetes Care. 2002;25(10):1729-36.

115. Byrkjeland R, Njerve IU, Anderssen S, Arnesen H, Seljeflot I, Solheim S. Effects of exercise training on $\mathrm{HbA1c}$ and VO2peak in patients with type 2 diabetes and coronary artery disease: a randomised clinical trial. Diabetes Vasc Dis Res. 2015;12(5):325-33.

116. DeBlieux PM, Barbee RW, McDonough KH, Shepherd RE. Exercise training improves cardiac performance in diabetic rats. Proc Soc Exp Biol Med Soc Exp Biol Med. 1993;203(2):209-13.

117. Broderick TL, Poirier P, Gillis M. Exercise training restores abnormal myocardial glucose utilization and cardiac function in diabetes. Diabetes Metab Res Rev. 2005;21(1):44-50.

118. De Angelis KL, Oliveira AR, Dall'Ago P, Peixoto LR, Gadonski G, Lacchini $S$, Fernandes TG, Irigoyen MC. Effects of exercise training on autonomic and myocardial dysfunction in streptozotocin-diabetic rats. Braz J Med Biol Res. 2000;33(6):635-41.

119. Rodrigues B, Jorge L, Mostarda CT, Rosa KT, Medeiros A, Malfitano C, de Souza AL Jr, Viegas KA, Lacchini S, Curi R, et al. Aerobic exercise training delays cardiac dysfunction and improves autonomic control of circulation in diabetic rats undergoing myocardial infarction. J Cardiac Fail. 2012;18(9):734-44.

120. Wisloff U, Stoylen A, Loennechen JP, Bruvold M, Rognmo O, Haram PM, Tjonna AE, Helgerud J, Slordahl SA, Lee SJ, et al. Superior cardiovascular effect of aerobic interval training versus moderate continuous training in heart failure patients: a randomized study. Circulation. 2007:115(24):3086-94.

121. Kodama S, Saito K, Tanaka S, Maki M, Yachi Y, Asumi M, Sugawara A, Totsuka K, Shimano H, Ohashi Y, et al. Cardiorespiratory fitness as a quantitative predictor of all-cause mortality and cardiovascular events in healthy men and women: a meta-analysis. JAMA. 2009;301 (19):2024-35.

122. Cuff DJ, Meneilly GS, Martin A, Ignaszewski A, Tildesley HD, Frohlich JJ. Effective exercise modality to reduce insulin resistance in women with type 2 diabetes. Diabetes Care. 2003:26(11):2977-82.

123. Kadoglou NP, Perrea D, lliadis F, Angelopoulou N, Liapis C, Alevizos M. Exercise reduces resistin and inflammatory cytokines in patients with type 2 diabetes. Diabetes Care. 2007;30(3):719-21.

124. Albright A, Franz M, Hornsby G, Kriska A, Marrero D, Ullrich I, Verity LS. American College of Sports Medicine position stand: exercise and type 2 diabetes. Med Sci Sports Exerc. 2000;32(7):1345-60.

125. Okada S, Hiuge A, Makino H, Nagumo A, Takaki H, Konishi H, Goto Y, Yoshimasa Y, Miyamoto Y. Effect of exercise intervention on endothelial function and incidence of cardiovascular disease in patients with type 2 diabetes. J Atheroscler Thromb. 2010;17(8):828-33.

126. Cohen ND, Dunstan DW, Robinson C, Vulikh E, Zimmet PZ, Shaw JE. Improved endothelial function following a 14-month resistance exercise training program in adults with type 2 diabetes. Diabetes Res Clin Pract. 2008;79(3):405-11.

127. Takase B, Uehata A, Akima T, Nagai T, Nishioka T, Hamabe A, Satomura K, Ohsuzu F, Kurita A. Endothelium-dependent flow-mediated vasodilation in coronary and brachial arteries in suspected coronary artery disease. Am J Cardiol. 1998;82(12):1535-9 (A1537-1538).

128. Kaku B, Mizuno S, Ohsato K, Murakami T, Moriuchi I, Arai Y, Nio Y, Takahashi Y. The correlation between coronary stenosis index and flow-mediated dilation of the brachial artery. Circulation. 1998:98(17):136-136.

129. Lee S, Park Y, Dellsperger KC, Zhang C. Exercise training improves endothelial function via adiponectin-dependent and independent pathways in type 2 diabetic mice. Am J Physiol Heart Circ Physiol. 2011:301(2):H306-14. 
130. Moien-Afshari F, Ghosh S, Elmi S, Rahman MM, Sallam N, Khazaei M, Kieffer TJ, Brownsey RW, Laher I. Exercise restores endothelial function independently of weight loss or hyperglycaemic status in $\mathrm{db} / \mathrm{db}$ mice. Diabetologia. 2008;51(7):1327-37.

131. Nichols GA, Joshua-Gotlib S, Parasuraman S. Glycemic control and risk of cardiovascular disease hospitalization and all-cause mortality. J Am Coll Cardiol. 2013:62(2):121-7.

132. Marwick TH, Hordern MD, Miller T, Chyun DA, Bertoni AG, Blumenthal RS, Philippides G, Rocchini A, Council on Clinical Cardiology AHAECR, Prevention C, et al. Exercise training for type 2 diabetes mellitus: impact on cardiovascular risk: a scientific statement from the American Heart Association. Circulation. 2009;1 19(25):3244-62.

133. Sluik D, Buijsse B, Muckelbauer R, Kaaks R, Teucher B, Johnsen NF, Tjonneland A, Overvad K, Ostergaard JN, Amiano P, et al. Physical activity and mortality in individuals with diabetes mellitus: a prospective study and meta-analysis. Arch Intern Med. 2012;172(17):1285-95.

134. Kodama S, Tanaka S, Heianza Y, Fujihara K, Horikawa C, Shimano H, Saito K, Yamada N, Ohashi Y, Sone H. Association between physical activity and risk of all-cause mortality and cardiovascular disease in patients with diabetes: a meta-analysis. Diabetes Care. 2013;36(2):471-9.

135. Mourier A, Gautier JF, De Kerviler E, Bigard AX, Villette JM, Garnier JP, Duvallet A, Guezennec CY, Cathelineau G. Mobilization of visceral adipose tissue related to the improvement in insulin sensitivity in response to physical training in NIDDM: effects of branched-chain amino acid supplements. Diabetes Care. 1997;20(3):385-91.

136. Kadoglou NP, lliadis F, Angelopoulou N, Perrea D, Ampatzidis G, Liapis $C D$, Alevizos M. The anti-inflammatory effects of exercise training in patients with type 2 diabetes mellitus. Eur J Cardiovasc Prev Rehabil. 2007:14(6):837-43.

137. Agurs-Collins TD, Kumanyika SK, Ten Have TR, Adams-Campbell LL. A randomized controlled trial of weight reduction and exercise for diabetes management in older African-American subjects. Diabetes Care. 1997:20(10):1503-11.

138. Dunstan DW, Mori TA, Puddey IB, Beilin L, Burke V, Morton AR, Stanton KG. The independent and combined effects of aerobic exercise and dietary fish intake on serum lipids and glycemic control in NIDDM: a randomized controlled study. Diabetes Care. 1997;20(6):913-21.

139. Rock CL, Flatt SW, Pakiz B, Taylor KS, Leone AF, Brelje K, Heath DD, Quintana EL, Sherwood NE. Weight loss, glycemic control, and cardiovascular disease risk factors in response to differential diet composition in a weight loss program in type 2 diabetes: a randomized controlled trial. Diabetes Care. 2014;37(6):1573-80.

140. Wing RR, Lang W, Wadden TA, Safford M, Knowler WC, Bertoni AG, Hill JO, Brancati FL, Peters A, Wagenknecht L, et al. Benefits of modest weight loss in improving cardiovascular risk factors in overweight and obese individuals with type 2 diabetes. Diabetes Care. 2011;34(7):1481-6.

141. Holten MK, Zacho M, Gaster M, Juel C, Wojtaszewski JF, Dela F. Strength training increases insulin-mediated glucose uptake, GLUT4 content, and insulin signaling in skeletal muscle in patients with type 2 diabetes. Diabetes. 2004;53(2):294-305.

142. Lauritzen HP, Galbo H, Toyoda T, Goodyear LJ. Kinetics of contractioninduced GLUT4 translocation in skeletal muscle fibers from living mice. Diabetes. 2010;59(9):2134-44.

143. Oguri M, Adachi H, Ohno T, Oshima S, Kurabayashi M. Effect of a single bout of moderate exercise on glucose uptake in type 2 diabetes mellitus. J Cardiol. 2009;53(1):8-14.

144. Sai E, Shimada K, Yokoyama T, Sato S, Miyazaki T, Hiki M, Tamura Y, Aoki $\mathrm{S}$, Watada H, Kawamori R, et al. Association between myocardial triglyceride content and cardiac function in healthy subjects and endurance athletes. PLoS ONE. 2013;8(4):e61604.

145. Schrauwen-Hinderling VB, Meex RC, Hesselink MK, van de Weijer T, Leiner T, Schar M, Lamb HJ, Wildberger JE, Glatz JF, Schrauwen P, et al. Cardiac lipid content is unresponsive to a physical activity training intervention in type 2 diabetic patients, despite improved ejection fraction. Cardiovasc Diabetol. 2011;10:47.

146. Hafstad AD, Lund J, Hadler-Olsen E, Hoper AC, Larsen TS, Aasum E. High- and moderate-intensity training normalizes ventricular function and mechanoenergetics in mice with diet-induced obesity. Diabetes. 2013;62(7):2287-94
147. Osborn BA, Daar JT, Laddaga RA, Romano FD, Paulson DJ. Exercise training increases sarcolemmal GLUT-4 protein and mRNA content in diabetic heart. J Appl Physiol. 1997;82(3):828-34.

148. Kim HJ, Lee JS, Kim CK. Effect of exercise training on muscle glucose transporter 4 protein and intramuscular lipid content in elderly men with impaired glucose tolerance. Eur J Appl Physiol. 2004;93(3):353-8.

149. Gertz EW, Wisneski JA, Stanley WC, Neese RA. Myocardial substrate utilization during exercise in humans: dual carbon-labeled carbohydrate isotope experiments. J Clin Investig. 1988;82(6):2017-25.

150. Sato K, Nishinaka Y, Morishita Y, Nakane K, Fukatsu T, Yokota M, Nakashima N. Myocardial metabolism during dynamic exercise. Rinsho Byori Jpn J Clin Pathol. 1993;41(9):1043-8.

151. Ceriello A, Motz E. Is oxidative stress the pathogenic mechanism underlying insulin resistance, diabetes, and cardiovascular disease? The common soil hypothesis revisited. Arterioscler Thromb Vasc. 2004;24(5):816-23.

152. Ansley DM, Wang B. Oxidative stress and myocardial injury in the diabetic heart. J Pathol. 2013;229(2):232-41.

153. Nojima H, Watanabe H, Yamane K, Kitahara Y, Sekikawa K, Yamamoto H, Yokoyama A, Inamizu T, Asahara T, Kohno N, et al. Effect of aerobic exercise training on oxidative stress in patients with type 2 diabetes mellitus. Metab Clin Exp. 2008:57(2):170-6.

154. Kurban S, Mehmetoglu I, Yerlikaya HF, Gonen S, Erdem S. Effect of chronic regular exercise on serum ischemia-modified albumin levels and oxidative stress in type 2 diabetes mellitus. Endocr Res. 2011;36(3):116-23.

155. Vinetti G, Mozzini C, Desenzani P, Boni E, Bulla L, Lorenzetti I, Romano C, Pasini A, Cominacini L, Assanelli D. Supervised exercise training reduces oxidative stress and cardiometabolic risk in adults with type 2 diabetes: a randomized controlled trial. Sci Rep. 2015;5:9238.

156. Hegde SV, Adhikari P, Kotian S, Pinto VJ, D'Souza S, D'Souza V. Effect of 3-month yoga on oxidative stress in type 2 diabetes with or without complications: a controlled clinical trial. Diabetes Care. 2011;34(10):2208-10

157. Iborra RT, Ribeiro IC, Neves MQ, Charf AM, Lottenberg SA, Negrao CE, Nakandakare ER, Passarelli M. Aerobic exercise training improves the role of high-density lipoprotein antioxidant and reduces plasma lipid peroxidation in type 2 diabetes mellitus. Scand J Med Sci Sports. 2008;18(6):742-50.

158. Neuparth MJ, Proenca JB, Santos-Silva A, Coimbra S. The positive effect of moderate walking exercise on chemerin levels in Portuguese patients with type 2 diabetes mellitus. J Investig Med. 2014;62(2):350-3.

159. Gordon LA, Morrison EY, McGrowder DA, Young R, Fraser YT, Zamora EM, Alexander-Lindo RL, Irving RR. Effect of exercise therapy on lipid profile and oxidative stress indicators in patients with type 2 diabetes. BMC Complement Altern Med. 2008:8:21.

160. Atalay M, Oksala NK, Laaksonen DE, Khanna S, Nakao C, Lappalainen J, Roy S, Hanninen O, Sen CK. Exercise training modulates heat shock protein response in diabetic rats. J Appl Physiol. 2004;97(2):605-11.

161. Muthusamy VR, Kannan S, Sadhaasivam K, Gounder SS, Davidson CJ, Boeheme C, Hoidal JR, Wang L, Rajasekaran NS. Acute exercise stress activates Nrf2/ARE signaling and promotes antioxidant mechanisms in the myocardium. Free Radic Biol Med. 2012;52(2):366-76.

162. Kaefer M, Piva SJ, De Carvalho JA, Da Silva DB, Becker AM, Coelho AC, Duarte MM, Moresco RN. Association between ischemia modified albumin, inflammation and hyperglycemia in type 2 diabetes mellitus. Clin Biochem. 2010;43(4-5):450-4.

163. Ma SG, Wei CL, Hong B, Yu WN. Ischemia-modified albumin in type 2 diabetic patients with and without peripheral arterial disease. Clinics. 2011;66(10):1677-80.

164. Sinha MK, Roy D, Gaze DC, Collinson PO, Kaski JC. Role of "Ischemia modified albumin", a new biochemical marker of myocardial ischaemia, in the early diagnosis of acute coronary syndromes. Emerg Med J. 2004:21(1):29-34.

165. Vepsalainen T, Soinio M, Marniemi J, Lehto S, Juutilainen A, Laakso M, Ronnemaa T. Physical activity, high-sensitivity C-reactive protein, and total and cardiovascular disease mortality in type 2 diabetes. Diabetes Care. 2011;34(7):1492-6.

166. Wallace TM, Levy JC, Matthews DR. Use and abuse of HOMA modeling. Diabetes Care. 2004:27(6):1487-95. 
167. Reilly MP, Lehrke M, Wolfe ML, Rohatgi A, Lazar MA, Rader DJ. Resistin is an inflammatory marker of atherosclerosis in humans. Circulation. 2005;111(7):932-9.

168. Zhang MH, Na B, Schiller NB, Whooley MA. Association of resistin with heart failure and mortality in patients with stable coronary heart disease: data from the heart and soul study. J Cardiac Fail. 2011;17(1):24-30.

169. Howlett KF, Sakamoto K, Hirshman MF, Aschenbach WG, Dow M, White MF, Goodyear LJ. Insulin signaling after exercise in insulin receptor substrate-2-deficient mice. Diabetes. 2002;51(2):479-83.

170. Huisamen $B$, Lochner A. Exercise modulates myocardial protein kinase B/Akt in Zucker obese rats. Heart. 2005;91(2):227-8.

171. Luciano E, Carneiro EM, Carvalho CR, Carvalheira JB, Peres SB, Reis MA, Saad MJ, Boschero AC, Velloso LA. Endurance training improves responsiveness to insulin and modulates insulin signal transduction through the phosphatidylinositol 3-kinase/Akt-1 pathway. Eur J Endocrinol. 2002;147(1):149-57.

172. Castorena CM, Arias EB, Sharma N, Cartee GD. Postexercise improvement in insulin-stimulated glucose uptake occurs concomitant with greater AS160 phosphorylation in muscle from normal and insulinresistant rats. Diabetes. 2014;63(7):2297-308.

173. Wang H, Bei Y, Lu Y, Sun W, Liu Q, Wang Y, Cao Y, Chen P, Xiao J, Kong X Exercise prevents cardiac injury and improves mitochondrial biogenesis in advanced diabetic cardiomyopathy with PGC-1alpha and Akt activation. Cell Physiol Biochem. 2015;35(6):2159-68.

174. Sriwijitkamol A, Ivy JL, Christ-Roberts C, DeFronzo RA, Mandarino LJ, Musi N. LKB1-AMPK signaling in muscle from obese insulin-resistant Zucker rats and effects of training. Am J Physiol Endocrinol Metab. 2006;290(5):E925-32.

175. Marinho R, Ropelle ER, Cintra DE, De Souza CT, Da Silva AS, Bertoli FC, Colantonio E, D'Almeida V, Pauli JR. Endurance exercise training increases APPL1 expression and improves insulin signaling in the hepatic tissue of diet-induced obese mice, independently of weight loss. J Cell Physiol. 2012;227(7):2917-26.

176. Kjobsted R, Munk-Hansen N, Birk JB, Foretz M, Viollet B, Bjornholm M, Zierath JR, Treebak JT, Wojtaszewski JF. Enhanced Muscle Insulin Sensitivity After Contraction/Exercise is Mediated by AMPK. Diab. 2016. doi:10.2337/db16-0530.

177. Bradley EA, Zhang L, Genders AJ, Richards SM, Rattigan S, Keske MA Enhancement of insulin-mediated rat muscle glucose uptake and microvascular perfusion by 5-aminoimidazole-4-carboxamide-1-betaD-ribofuranoside. Cardiovasc Diabetol. 2015;14:91

178. Lin J, Puigserver P, Donovan J, Tarr P, Spiegelman BM. Peroxisome proliferator-activated receptor gamma coactivator 1 beta (PGC-1 beta), a novel PGC-1-related transcription coactivator associated with host cell factor. J Biol Chem. 2002;277(3):1645-8.

179. Ventura-Clapier R, Garnier A, Veksler V. Transcriptional control of mitochondrial biogenesis: the central role of PGC-1alpha. Cardiovasc Res. 2008;79(2):208-17.

180. Massart J, Katayama M, Krook A. microManaging glucose and lipid metabolism in skeletal muscle: role of microRNAs. Biochim Biophys Acta. 2016;1861(12 Pt B):2130-8.

181. Kleiner S, Mepani RJ, Laznik D, Ye L, Jurczak MJ, Jornayvaz FR, Estall JL, Chatterjee Bhowmick D, Shulman Gl, Spiegelman BM. Development of insulin resistance in mice lacking PGC-1alpha in adipose tissues. Proc Natl Acad Sci USA. 2012;109(24):9635-40

182. Summermatter S, Shui G, Maag D, Santos G, Wenk MR, Handschin C. PGC-1alpha improves glucose homeostasis in skeletal muscle in an activity-dependent manner. Diabetes. 2013;62(1):85-95.

183. Chinsomboon J, Ruas J, Gupta RK, Thom R, Shoag J, Rowe GC, Sawada $\mathrm{N}$, Raghuram S, Arany Z. The transcriptional coactivator PGC-1alpha mediates exercise-induced angiogenesis in skeletal muscle. Proc Natl Acad Sci USA. 2009;106(50):21401-6

184. Marcinko K, Sikkema SR, Samaan MC, Kemp BE, Fullerton MD, Steinberg GR. High intensity interval training improves liver and adipose tissue insulin sensitivity. Mol Metab. 2015;4(12):903-15.

185. Jager S, Handschin C, St-Pierre J, Spiegelman BM. AMP-activated protein kinase (AMPK) action in skeletal muscle via direct phosphorylation of PGC-1alpha. Proc Natl Acad Sci USA. 2007;104(29):12017-22.

186. Hoshino D, Yoshida Y, Kitaoka Y, Hatta H, Bonen A. High-intensity interval training increases intrinsic rates of mitochondrial fatty acid oxidation in rat red and white skeletal muscle. Appl Physiol Nutr Metab. 2013;38(3):326-33.

187. Mehlem A, Palombo I, Wang X, Hagberg CE, Eriksson U, Falkevall A. PGC1alpha coordinates mitochondrial respiratory capacity and muscular fatty acid uptake via regulation of VEGF-B. Diabetes. 2016;65(4):861-73.

188. Kirwan JP, del Aguila LF, Hernandez JM, Williamson DL, O'Gorman DJ, Lewis R, Krishnan RK. Regular exercise enhances insulin activation of IRS-1-associated PI3-kinase in human skeletal muscle. J Appl Physiol. 2000:88(2):797-803.

189. Wadley GD, Tunstall RJ, Sanigorski A, Collier GR, Hargreaves M, Cameron-Smith D. Differential effects of exercise on insulin-signaling gene expression in human skeletal muscle. J Appl Physiol. 2001;90(2):436-40.

190. Jorge ML, de Oliveira VN, Resende NM, Paraiso LF, Calixto A, Diniz AL, Resende ES, Ropelle ER, Carvalheira JB, Espindola FS, et al. The effects of aerobic, resistance, and combined exercise on metabolic control, inflammatory markers, adipocytokines, and muscle insulin signaling in patients with type 2 diabetes mellitus. Metab Clin Exp. 2011;60(9):1244-52.

191. Rawal S, Manning P, Katare R. Cardiovascular microRNAs: as modulators and diagnostic biomarkers of diabetic heart disease. Cardiovasc Diabetol. 2014;13:44.

192. Duisters RF, Tijsen AJ, Schroen B, Leenders JJ, Lentink V, van der Made I, Herias V, van Leeuwen RE, Schellings MW, Barenbrug P, et al. miR-133 and miR-30 regulate connective tissue growth factor: implications for a role of microRNAs in myocardial matrix remodeling. Circ Res. 2009;104(2):170-8 (176p following 178).

193. Feng B, Chen S, George B, Feng Q, Chakrabarti S. miR133a regulates cardiomyocyte hypertrophy in diabetes. Diabetes Metab Res Rev. 2010;26(1):40-9.

194. Belevych AE, Sansom SE, Terentyeva R, Ho HT, Nishijima Y, Martin MM, Jindal HK, Rochira JA, Kunitomo Y, Abdellatif M, et al. MicroRNA-1 and -133 increase arrhythmogenesis in heart failure by dissociating phosphatase activity from RyR2 complex. PLoS ONE. 2011;6(12):e28324.

195. Chen S, Puthanveetil P, Feng B, Matkovich SJ, Dorn GW 2nd, Chakrabarti S. Cardiac miR-133a overexpression prevents early cardiac fibrosis in diabetes. J Cell Mol Med. 2014;18(3):415-21.

196. Izarra A, Moscoso I, Levent E, Canon S, Cerrada I, Diez-Juan A, Blanca V, Nunez-Gil IJ, Valiente I, Ruiz-Sauri A, et al. miR-133a enhances the protective capacity of cardiac progenitors cells after myocardial infarction. Stem Cell Rep. 2014;3(6):1029-42.

197. He B, Xiao J, Ren AJ, Zhang YF, Zhang H, Chen M, Xie B, Gao XG, Wang YW. Role of miR-1 and miR-133a in myocardial ischemic postconditioning. J Biomed Sci. 2011;18:22.

198. Russell AP, Lamon S, Boon H, Wada S, Guller I, Brown EL, Chibalin AV, Zierath JR, Snow RJ, Stepto N, et al. Regulation of miRNAs in human skeletal muscle following acute endurance exercise and short-term endurance training. J Physiol. 2013;591(Pt 18):4637-53.

199. Nielsen S, Scheele C, Yfanti C, Akerstrom T, Nielsen AR, Pedersen BK, Laye MJ. Muscle specific microRNAs are regulated by endurance exercise in human skeletal muscle. J Physiol. 2010;588(Pt 20):4029-37.

200. Mooren FC, Viereck J, Kruger K, Thum T. Circulating micrornas as potential biomarkers of aerobic exercise capacity. Am J Physiol-Heart C. 2014;306(4):H557-63.

201. Nielsen S, Akerstrom T, Rinnov A, Yfanti C, Scheele C, Pedersen BK, Laye $\mathrm{MJ}$. The miRNA plasma signature in response to acute aerobic exercise and endurance training. PLoS ONE. 2014;9(2):e87308.

202. Uhlemann M, Mobius-Winkler S, Fikenzer S, Adam J, Redlich M, Mohlenkamp S, Hilberg T, Schuler GC, Adams V. Circulating microRNA-126 increases after different forms of endurance exercise in healthy adults. Eur J Prev Cardiol. 2014:21(4):484-91.

203. Mishra PK, Awe O, Metreveli N, Qipshidze N, Munjal C, Tyagi N, Tyagi SC. Exercise ameliorates diabetic cardiomyopathy by inducing beta2adrenergic receptors and miR-133a, and attenuating MMP-9. Faseb J. 2011;25:1032-4.

204. Steensberg A, van Hall G, Osada T, Sacchetti M, Saltin B, Pedersen BK. Production of interleukin-6 in contracting human skeletal muscles can account for the exercise-induced increase in plasma interleukin-6. J Physiol. 2000;529(Pt 1):237-42.

205. Glund S, Deshmukh A, Long YC, Moller T, Koistinen HA, Caidahl K, Zierath JR, Krook A. Interleukin-6 directly increases glucose metabolism in resting human skeletal muscle. Diabetes. 2007;56(6):1630-7. 
206. Rawal S, Ram TP, Coffey S, Williams MJ, Saxena P, Bunton RW, Galvin IF, Katare R. Differential expression pattern of cardiovascular microRNAs in the human type-2 diabetic heart with normal ejection fraction. Int $J$ Cardiol. 2016;202:40-3.

207. Yildirim SS, Akman D, Catalucci D, Turan B. Relationship between downregulation of miRNAs and increase of oxidative stress in the development of diabetic cardiac dysfunction: junctin as a target protein of miR-1. Cell Biochem Biophys. 2013;67(3):1397-408.

208. Hong CS, Kwon SJ, Cho MC, Kwak YG, Ha KC, Hong B, Li H, Chae SW, $\mathrm{Chai} \mathrm{OH}$, Song $\mathrm{CH}$, et al. Overexpression of junctate induces cardiac hypertrophy and arrhythmia via altered calcium handling. J Mol Cell Cardiol. 2008:44(4):672-82.

209. Kirchhefer U, Hanske G, Jones LR, Justus I, Kaestner L, Lipp P, Schmitz $W$, Neumann J. Overexpression of junction causes adaptive changes in cardiac myocyte $\mathrm{Ca}(2+)$ signaling. Cell Calcium. 2006;39(2):131-42.

210. Wang J, Jia Z, Zhang C, Sun M, Wang W, Chen P, Ma K, Zhang Y, Li X, Zhou C. miR-499 protects cardiomyocytes from $\mathrm{H}_{2} \mathrm{O}_{2}$-induced apoptosis via its effects on Pdcd4 and Pacs2. RNA Biol. 2014;11 (4):339-50.

211. Liu X, Cheng Y, Zhang S, Lin Y, Yang J, Zhang C. A necessary role of miR-221 and miR-222 in vascular smooth muscle cell proliferation and neointimal hyperplasia. Circ Res. 2009;104(4):476-87.

212. Togliatto G, Trombetta A, Dentelli P, Rosso A, Brizzi MF. MIR221/MIR222driven post-transcriptional regulation of P27KIP1 and P57KIP2 is crucial for high-glucose- and AGE-mediated vascular cell damage. Diabetologia. 2011;54(7):1930-40.

213. Jiang Y, Wang HY, Li Y, Guo SH, Zhang L, Cai JH. Peripheral blood miRNAs as a biomarker for chronic cardiovascular diseases. Sci Rep. 2014;4:5026.

214. Liu X, Xiao J, Zhu H, Wei X, Platt C, Damilano F, Xiao C, Bezzerides V, Bostrom $P, C$, $L$, et al. miR-222 is necessary for exercise-induced cardiac growth and protects against pathological cardiac remodeling. Cell Metab. 2015;21(4):584-95.

215. Fish JE, Santoro MM, Morton SU, Yu S, Yeh RF, Wythe JD, Ivey KN, Bruneau BG, Stainier DY, Srivastava D. miR-126 regulates angiogenic signaling and vascular integrity. Dev Cell. 2008;15(2):272-84.

216. Wang S, Aurora AB, Johnson BA, Qi X, McAnally J, Hill JA, Richardson $J$ A, Bassel-Duby R, Olson EN. The endothelial-specific microRNA miR-126 governs vascular integrity and angiogenesis. Dev Cell. 2008:15(2):261-71.

217. Jansen F, Yang $X$, Hoelscher M, Cattelan A, Schmitz T, Proebsting S, Wenzel D, Vosen S, Franklin BS, Fleischmann BK, et al. Endothelial microparticle-mediated transfer of MicroRNA-126 promotes vascular endothelial cell repair via SPRED1 and is abrogated in glucose-damaged endothelial microparticles. Circulation. 2013;128(18):2026-38.

218. Zampetaki A, Kiechl S, Drozdov I, Willeit P, Mayr U, Prokopi M, Mayr A, Weger S, Oberhollenzer F, Bonora E, et al. Plasma microRNA profiling reveals loss of endothelial miR-126 and other microRNAs in type 2 diabetes. Circ Res. 2010;107(6):810-7.

219. Fichtlscherer S, De Rosa S, Fox H, Schwietz T, Fischer A, Liebetrau C, Weber M, Hamm CW, Roxe T, Muller-Ardogan M, et al. Circulating microRNAs in patients with coronary artery disease. Circ Res. 2010;107(5):677-84

220. Jansen F, Wang H, Przybilla D, Franklin BS, Dolf A, Pfeifer P, Schmitz T, Flender A, Endl E, Nickenig G, et al. Vascular endothelial microparticlesincorporated microRNAs are altered in patients with diabetes mellitus. Cardiovasc Diabetol. 2016;15:49.

221. Rawal S, Munasinghe P, Shindikar A, Paulin J, Cameron V, Manning P, Williams M, Jones GT, Bunton R, Galvin I, et al. Down-regulation of proangiogenic microRNA-126 and microRNA-132 are early modulators of diabetic cardiac microangiopathy. Cardiovasc Res. 2016. doi:10.1093/ $\mathrm{cvr} / \mathrm{crw} 235$

222. Silva DA, Jr ND, Fernandes T, Soci UP, Monteiro AW, Phillips MI, de Oliveira EM. Swimming training in rats increases cardiac MicroRNA-126 expression and angiogenesis. Med Sci Sports exerc. 2012;44(8):1453-62.

223. Ikeda S, He A, Kong SW, Lu J, Bejar R, Bodyak N, Lee KH, Ma Q, Kang PM, Golub TR, et al. MicroRNA-1 negatively regulates expression of the hypertrophy-associated calmodulin and Mef2a genes. Mol Cell Biol. 2009;29(8):2193-204.

224. Callis TE, Pandya K, Seok HY, Tang RH, Tatsuguchi M, Huang ZP, Chen JF, Deng Z, Gunn B, Shumate J, et al. MicroRNA-208a is a regulator of cardiac hypertrophy and conduction in mice. J Clin Investig. 2009;119(9):2772-86.
225. Satoh M, Minami Y, Takahashi Y, Tabuchi T, Nakamura M. Expression of microRNA-208 is associated with adverse clinical outcomes in human dilated cardiomyopathy. J Cardiac Fail. 2010;16(5):404-10.

226. Ling TY, Wang XL, Chai Q, Lau TW, Koestler CM, Park SJ, Daly RC, Greason KL, Jen J, Wu LQ, et al. Regulation of the SK3 channel by microRNA-499-potential role in atrial fibrillation. Heart Rhythm. 2013;10(7):1001-9.

227. Sluijter JP, van Mil A, van Vliet P, Metz CH, Liu J, Doevendans PA, Goumans MJ. MicroRNA-1 and-499 regulate differentiation and proliferation in human-derived cardiomyocyte progenitor cells. Arterioscler Thromb Vasc Biol. 2010;30(4):859-68.

228. van Solingen C, Seghers L, Bijkerk R, Duijs JM, Roeten MK, van OeverenRietdijk AM, Baelde HJ, Monge M, Vos JB, de Boer HC, et al. Antagomirmediated silencing of endothelial cell specific microRNA-126 impairs ischemia-induced angiogenesis. J Cell Mol Med. 2009;13(8A):1577-85.

229. Zernecke A, Bidzhekov K, Noels H, Shagdarsuren E, Gan L, Denecke B, Hristov M, Koppel T, Jahantigh MN, Lutgens E, et al. Delivery of microRNA-126 by apoptotic bodies induces CXCL12-dependent vascular protection. Sci Signal. 2009;2(100):ra81.

230. Vickers KC, Palmisano BT, Shoucri BM, Shamburek RD, Remaley AT. MicroRNAs are transported in plasma and delivered to recipient cells by high-density lipoproteins. Nat Cell Biol. 2011;13(4):423-33.

231. Flowers E, Aouizerat BE, Abbasi F, Lamendola C, Grove KM, Fukuoka Y, Reaven GM. Circulating microRNA-320a and microRNA-486 predict thiazolidinedione response: moving towards precision health for diabetes prevention. Metab Clin Exp. 2015;64(9):1051-9.

232. Ponomaryova AA, Morozkin ES, Rykova EY, Zaporozhchenko IA, Skvortsova TE, Dobrodeev AY, Zavyalov AA, Tuzikov SA, Vlassov WV, Cherdyntseva NV, et al. Dynamic changes in circulating miRNA levels in response to antitumor therapy of lung cancer. Exp Lung Res. 2016;42(2):95-102.

233. Granjon A, Gustin MP, Rieusset J, Lefai E, Meugnier E, Guller I, Cerutti C, Paultre C, Disse E, Rabasa-Lhoret R, et al. The microRNA signature in response to insulin reveals its implication in the transcriptional action of insulin in human skeletal muscle and the role of a sterol regulatory element-binding protein-1 c/myocyte enhancer factor $2 \mathrm{C}$ pathway. Diabetes. 2009;58(11):2555-64.

234. miRagen therapeutics: pipeline. http://miragentherapeutics.com/ pipeline/. Accessed 29 April 2016.

235. Janssen HL, Reesink HW, Lawitz EJ, Zeuzem S, Rodriguez-Torres M, Patel K, van der Meer AJ, Patick AK, Chen A, Zhou Y, et al. Treatment of HCV infection by targeting microRNA. N Engl J Med. 2013;368(18):1685-94.

236. Perri MG, Anton SD, Durning PE, Ketterson TU, Sydeman SJ, Berlant NE, Kanasky WF Jr, Newton RL Jr, Limacher MC, Martin AD. Adherence to exercise prescriptions: effects of prescribing moderate versus higher levels of intensity and frequency. Health Psychol. 2002;21 (5):452-8.

237. Karakikes I, Chaanine AH, Kang S, Mukete BN, Jeong D, Zhang S, Hajjar RJ, Lebeche D. Therapeutic cardiac-targeted delivery of miR-1 reverses pressure overload-induced cardiac hypertrophy and attenuates pathological remodeling. J Am Heart Assoc. 2013;2(2):e000078.

\section{Submit your next manuscript to BioMed Central and we will help you at every step:}

- We accept pre-submission inquiries

- Our selector tool helps you to find the most relevant journal

- We provide round the clock customer support

- Convenient online submission

- Thorough peer review

- Inclusion in PubMed and all major indexing services

- Maximum visibility for your research

Submit your manuscript at www.biomedcentral.com/submit 